Proceedings of the Annual Scientific Meeting of the International Medical Society of Paraplegia held at Heidelberg (Germany) on 3rd to 5th August 1972.

\title{
CURRENT FACTS ON PARA-OSTEO-ARTHROPATHY (POA)
}

A. B. Rossier, ${ }^{1}$ M.D., ${ }^{*}$ Ph. Bussat, ${ }^{2}$ M.D., PD, F. Infante, ${ }^{3}$ M.D., R. Zender, ${ }^{4}$ Dr.ès Sc., B. Courvoisier, ${ }^{5}$ M.D., G. Muheim, ${ }^{6}$ M.D., A. Donath, ${ }^{7}$ M.D., H. Vasey, ${ }^{8}$ M.D., W. TaIllard, ${ }^{9}$ M.D., R. Lagier, ${ }^{10}$ M.D., G. Gabbiani, ${ }^{11}$ M.D., C. A. Baud, ${ }^{12}$ M.D., J. A. Pouezat, ${ }^{13}$ D.D.S., J. M. Very, ${ }^{14}$ Ph.D., H. J. HaChen, ${ }^{15}$ M.D.

1 Spinal Cord Injury Centre, Institute for Physical Medicine and Rehabilitation

${ }^{2}$ Radiological Institute, Chief of the Angiography Unit

3 Laboratory of the Surgical Clinic

4 Laboratory of La Chaux-de-Fonds Hospital

5 Medical Therapeutic Clinic, Department of Internal Medicine

6 Division of Orthopaedics, Department of Surgery

7 Division of Nuclear Medicine, Department of Internal Medicine

8 and ${ }^{9}$ Division of Orthopaedics, Department of Surgery

10 Department of Pathology

11 Department of Pathology

12 Department of Morphology, University Medical School

13 and ${ }^{14}$ Department of Morphology, University Medical School

15 Spinal Cord Injury Centre, Institute for Physical Medicine and Rehabilitation

University Hospital, Geneva, Switzerland

\section{INTRODUCTION}

SINCE the original investigations by Déjerine and Ceillier (1918), and Déjerine et al. (I9I9), many studies have been devoted to POA, unfortunately making no new contribution to the state of our knowledge, with the exception of three basic articles (Bénassy et al., 1960; Furman et al., 1970; Galibert et al., 1961).

Starting from the observations by Claude Bernard, who noted, in 1859 , the red colour of venous blood in animals whose spinal cord had been sectioned, Bénassy et al. (1960, 1963) demonstrated the presence of arterialised venous blood in the paralysed territories of para- and tetraplegic patients. Galibert et al. (I96I) demonstrated angiographically, the presence of early venous return in a number of paraplegic patients. These authors suggested that vascular anomalies may play a role in the formation of POA. Furman et al. (1970) demonstrated that the formation of POA is associated with an elevation of the serum alkaline phosphatase, confirming the observation of Mead et al. (1963).

Stimulated by the findings of these workers, the authors decided to review the problem of POA, from the beginning, in order to try and answer the following basic questions:

* Address for reprints: A. B. Rossier, M.D., Prof essor for Spinal Cord Rehabilitation and Social Medicine, Harvard Medical School; Chief, Spinal Cord Injury Service, V. A. Hospital, West Roxbury, Mass. 02132 , U.S.A. 
I. What are the aetiology and pathogenesis of POA?

2. At what point may one consider the POA bone maturation complete, and consequently, when is surgery indicated?

It is known that to operate when the POA bone maturation is incomplete is to court recurrence in a high percentage of cases. But there is no alternative to surgical intervention when the POA process limits articular freedom (hip joints above all) to the extent of the patient becoming so dependent that he is unable to use even a wheelchair.

The following parameters were investigated:

$\mathrm{X}$-rays; lower limb angiography with venous and arterial blood gas determinations; serial determinations of urine hydroxyproline (Hyp); urine calcium; serum calcium and phosphorus; creatinephosphokinase (CPK); alkaline phosphatase; bone scans, skin temperatures; bone biopsies in evolving POA; photographs of operative procedures and of gross specimens to be coordinated with light and electron microscope studies; analysis of amorphous and crystalline mineral components and fluorescent study of ectopic bone marked with tetracycline during its formation.

In this report, it has been decided not to discuss and review aspects of POA already published during the past few years. The purpose of this is so that only new facts resulting from this study are presented.

\section{CRITERIA OF PROGRESSION AND MATURATION OF POA}

\section{A. Radiographs}

The earliest radiologic signs of POA are usually preceded, in patients who may also be febrile, by one or more of the following articular signs: rubor, calor, tumor, dolor, hydarthrosis and impaired articular range of motion. Radiological signs are therefore, usually not the key to the early diagnosis of POA. Frequently, the earliest radiological manifestations of POA are to be found on lateral films, when the antero-posterior films are still unremarkable (fig. I, $c$ ). In two cases of acute POA (Table $\mathrm{I}^{1}$, cases $\mathrm{I}$ and 2 ), followed from the first appearance of clinical signs, we noted on films taken I-2 days after onset of clinical signs, an increase in density of the soft tissues of the thigh (fig. $\mathrm{I}, a$ ). On the other hand, once radiological signs of POA have made their appearance, a lack of change in these signs cannot be interpreted as indicative of lack of POA activity, since it is known that POA can evolve in the absence of change in radiologic signs already present. Couvée (I97I)had stated to the contrary, that 'the X-ray photograph may clearly show when the bone formation is mature'. In other words, in agreement with Furman et al. (1970), whether the POA is incipient, or old (several weeks or even years), the $X$-ray signs lag behind the evolution of the POA.

This observation is confirmed by the following:

(a) In cases I and 2, where we were able to follow a POA from its inception, the first X-rays, taken the day of the onset of clinical signs, showed no abnormality (fig. I, $a-c$ ). All serum chemistry determinations were found to be within normal limits at that time, including the alkaline phosphatase (Tables II and III).

${ }^{1}$ Information concerning the case of each patient mentioned in this study in to be found in Table I. 
(b) In the two patients (cases 3 and 4) in whom we had a post-operative recurrence of the POA, the pre-operative X-rays showed no change for a period of 3 months prior to the operation in case $4 ; 5$ months in case 3 . In the latter case (Table IV), the POA was diagnosed $2 \frac{1}{2}$ years previously. It must be concluded, therefore, that the waiting period before operation of 3-4 months advocated by Hardy and Dickson (1963) and Radt (1970) and up to I year, as advocated by Grogono (I966) and Jeannopoulos and Leventen (I96I) may be insufficient in some cases.


Fig. I (Case I)

A, AP X-ray of the left femur 2 days after onset of clinical signs: no POA is visible. B, AP X-ray of the left femur 5 days later: no POA can be seen. C, Lateral X-ray view of the left femur I 4 days after clinical onset: POA becomes radiologically visible; this POA was not visible on the AP film taken at the same time.

The X-ray, however, becomes a valuable diagnostic aid when it shows modifications from one examination to another, usually an increase in the mass of ectopic bone, or a change in its texture. These changes may be extended over a period of weeks, or even months (Table V). Rarely, a regression of the POA may be observed (fig. 2, $a, b$ ).

\section{CONCLUSION}

$\mathrm{X}$-ray evidence alone cannot determine whether a POA has reached maturation and stability, both because of the lack of objective criteria and because X-ray signs lag behind the evolution of the POA. 


\section{TABLE I}

Information chart concerning the case of each patient mentioned in the study

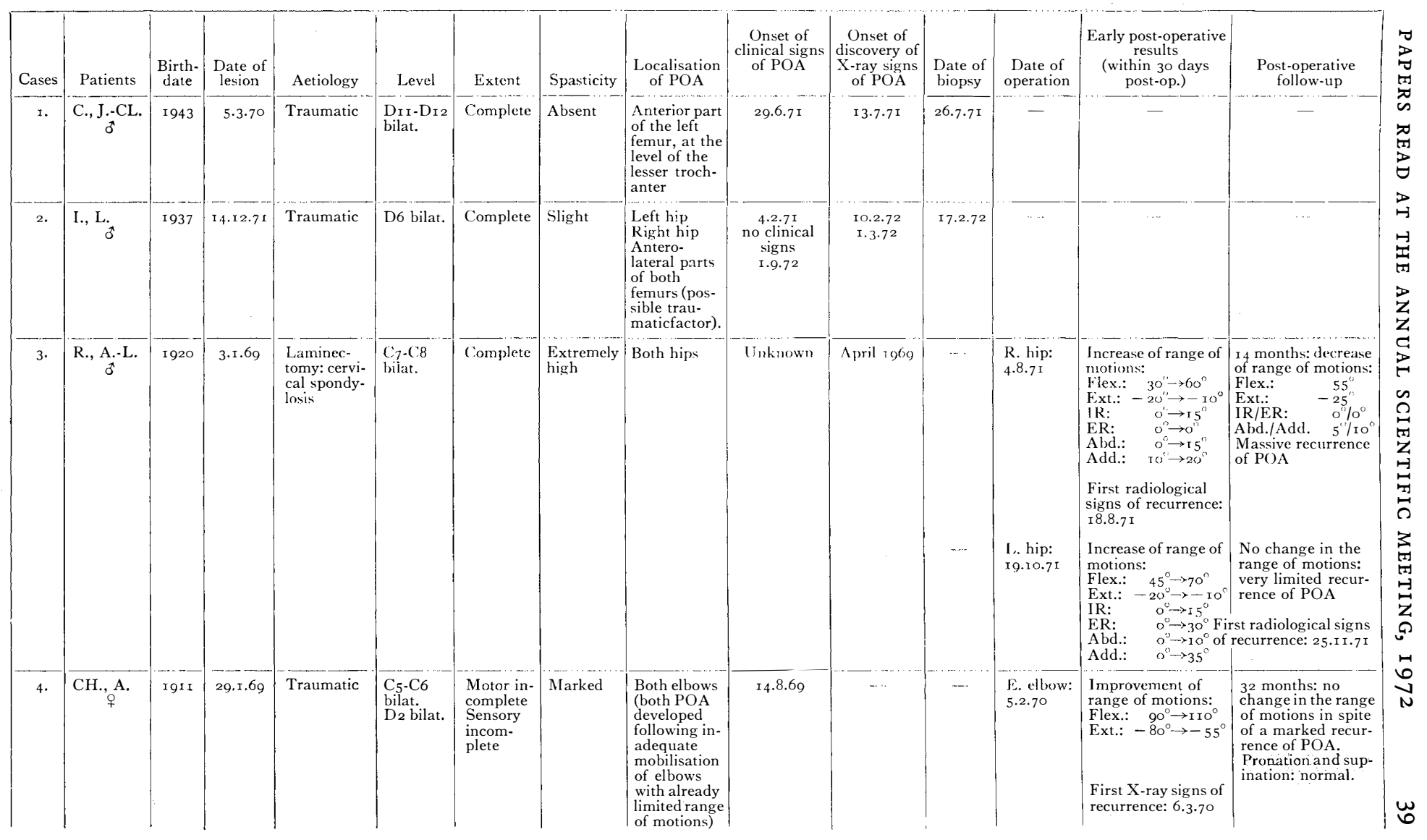

(continued overleaf) 
TABLE I continued

\begin{tabular}{|c|c|c|c|c|c|c|c|c|c|c|c|c|c|c|}
\hline Cases & Patients & $\begin{array}{c}\text { Birth- } \\
\text { date }\end{array}$ & $\begin{array}{l}\text { Date of } \\
\text { lesion }\end{array}$ & Aetiology & Level & Extent & Spasticity & $\begin{array}{l}\text { Localisation } \\
\text { of POA }\end{array}$ & $\begin{array}{c}\text { Onset of } \\
\text { clinical signs } \\
\text { of POA }\end{array}$ & $\begin{array}{c}\text { Onset of } \\
\text { discovery of } \\
\text { X-ray signs } \\
\text { of POA }\end{array}$ & $\begin{array}{l}\text { Date of } \\
\text { biopsy }\end{array}$ & $\begin{array}{c}\text { Date of } \\
\text { operation }\end{array}$ & \begin{tabular}{|c|} 
Early post-operative \\
results \\
(within 30 days \\
post op.)
\end{tabular} & $\begin{array}{l}\text { Post-operative } \\
\text { follow-up }\end{array}$ \\
\hline & & & & & & & & & & & & $\begin{array}{l}\text { L. elbow: } \\
\text { 29.10.70 }\end{array}$ & $\begin{array}{l}\text { Improvement of } \\
\text { range of motions: } \\
\text { Flex.: } 90^{\circ} \rightarrow 115^{\circ} \\
\text { Ext.: }-90^{\circ} \rightarrow-25^{\circ} \\
\\
\text { X-ray signs of a } \\
\text { fracture of the } \\
\text { humeral epiphysis } \\
\text { and of recurrence of } \\
\text { POA: } 30.11 .70\end{array}$ & $\begin{array}{l}24 \text { months: decrease } \\
\text { of range of motions: } \\
\text { Flex.: I 1 } 0^{\circ} \\
\text { Ext.: }-90^{\circ} \\
\text { Very marked recur- } \\
\text { rence of POA } \\
\text { Pronation and sup- } \\
\text { ination: normal. }\end{array}$ \\
\hline 5. & H., $\underset{0}{\text { W. }}$ & 1927 & 29.1 I. 7 I & Traumatic & $\left.\begin{array}{l}\mathrm{C}_{4}-\mathrm{C}_{5} \\
\text { bilat. } \\
\text { C6 } \\
\text { bilat. }\end{array}\right\}$ & $\begin{array}{c}\text { In- } \\
\text { complete } \\
\text { Complete }\end{array}$ & Excessive & $\begin{array}{l}\text { Lesser troch- } \\
\text { anter on } \\
\text { both sides }\end{array}$ & $9 \cdot 3 \cdot 72$ & 10.3 .72 & - & - & - & - \\
\hline 6. & I., J. & 1935 & $2.8 .7 \mathrm{I}$ & Traumatic & $\begin{array}{l}\mathrm{DI}_{2-\mathrm{LI}} \\
\text { bilat. }\end{array}$ & Complete & Absent & $\begin{array}{l}\text { Both medial } \\
\text { femoral con- } \\
\text { dyles }\end{array}$ & $29.9 \cdot 7 \mathrm{I}$ & 21.10 .71 & $29 \cdot 10.7 \mathrm{I}$ & - & - & - \\
\hline 7. & P., $L_{\text {i }}$ & 1952 & 30.7 .70 & Traumatic & $\left.\begin{array}{l}\mathrm{C}_{7} \text {-C8 } \\
\text { bilat. }\end{array}\right\}$ & $\begin{array}{l}\text { Sensory } \\
\text { incom- } \\
\text { plete } \\
\text { Motor } \\
\text { complete }\end{array}$ & Moderate & $\begin{array}{l}\text { Anterior } \\
\text { Superior } \\
\text { Iliac spines }\end{array}$ & - & 27.10 .70 & - & - & - & - \\
\hline 8. & M., G. & 1927 & 24.6 .66 & Traumatic & $\begin{array}{l}\mathrm{C}_{5}-\mathrm{C} 6 \\
\text { bilat. }\end{array}$ & Complete & $\widetilde{\text { Moderate }}$ & Left hip & 3.8 .66 & I1.10.66 & - & 10.6.70 & $\begin{array}{l}\text { Flex.: } \quad 85^{\circ} \\
\text { Ext.: } \quad-20^{\circ} \\
\text { Abd./Add.: } 40^{\circ} / 30^{\circ} \\
\text { IR/ER: } \quad 10^{\circ} / 15^{\circ} \\
\text { Pre-op.: } \\
\text { Hip ankylosed in } \\
25^{\circ} \text { flexion }\end{array}$ & 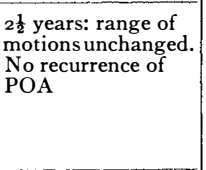 \\
\hline 9. & B., $P_{\text {i }}$ & I 945 & 7.10.70 & $\begin{array}{l}\text { Head } \\
\text { trauma }\end{array}$ & $\begin{array}{l}\text { Left } \\
\text { hemiple- } \\
\text { gia after } \\
\text { nitial } \\
\text { decere- } \\
\text { bration. }\end{array}$ & $\begin{array}{l}\text { In- } \\
\text { complete }\end{array}$ & Marked & $\begin{array}{l}\text { Left elbow } \\
\text { Left shoulder } \\
\text { Right hip }\end{array}$ & 二 & $\begin{array}{l}\text { IO.12.70 } \\
25.11 .70 \\
22.3 .71\end{array}$ & - & - & - & - \\
\hline ro. & D., $\underset{\delta}{\mathrm{M}}$. & 1953 & 19.2.68 & $\begin{array}{l}\text { Guillain- } \\
\text { Barré }\end{array}$ & - & $\begin{array}{l}\text { Tibialis } \\
\text { ant., } \\
\text { Peroneus } \\
\text { brevis and } \\
\text { toes } \\
\text { muscles } \\
\text { on both } \\
\text { sides at } O \text {. }\end{array}$ & Absent & Both hips & 16.4.68 & го.6.68 & - & $\begin{array}{l}\text { L. hip: } \\
\text { I6.II.7I } \\
\\
\text { R. hip: } \\
9.2 .72\end{array}$ & $\begin{array}{l}\text { Pre-op.: } \\
\text { hip ankylosed } \\
\text { Pre-op.: } \\
\text { hip ankylosed }\end{array}$ & 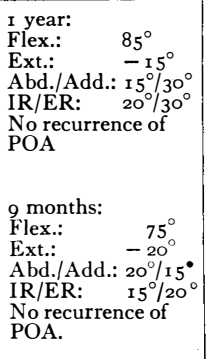 \\
\hline
\end{tabular}




\begin{tabular}{|c|c|c|c|c|c|c|c|c|c|c|c|c|c|c|}
\hline II. & D., $\underset{\delta}{\mathrm{H}}$. & I 947 & 23.8 .68 & Traumatic & D8 bilat. & $\begin{array}{l}\text { Sensory: } \\
\text { incom- } \\
\text { complete } \\
\text { Motor: } \\
\text { complete }\end{array}$ & Marked & $\begin{array}{l}\text { Both knees } \\
\text { and femoral } \\
\text { shafts }\end{array}$ & $\begin{array}{l}\text { About } 3 \\
\text { weeks post- } \\
\text { trauma. }\end{array}$ & - & - & - & - & - \\
\hline 13. & B., $\underset{\delta}{\text { M. }}$ & I 94 I & 25.5 .69 & Traumatic & $\begin{array}{l}\mathrm{L}_{3}-\mathrm{L}_{4} \\
\text { bilat. } \\
\mathrm{L}_{2} \\
\text { bilat. }\end{array}$ & $\begin{array}{l}\left\{\begin{array}{l}\text { Sensory } \\
\text { complete }\end{array}\right. \\
\left\{\begin{array}{l}\text { Motor } \\
\text { complete }\end{array}\right.\end{array}$ & Slight & Left hip & 28.6 .69 & 28.6 .69 & - & 5.2 .70 & $\begin{array}{l}\text { Pre-op.: } \\
\text { Flex.: } 30^{\circ} \\
\text { Ext.: } 0^{\circ} \\
\text { No other move- } \\
\text { ments }\end{array}$ & $\begin{array}{l}32 \text { months: } \\
\text { Flex.: ir } 15^{\circ} \\
\text { Ext.: o } \\
\text { Abd./Add.: } 30^{\circ} / 20^{\circ} \\
\text { IR/ER: } 15^{\circ} / 25^{\circ}\end{array}$ \\
\hline 14. & C., B. & I939 & 18.1.67 & Traumatic & $\begin{array}{l}\mathrm{C}_{7} \text { bilat. } \\
\mathrm{D}_{\text {I }} \text { bilat. }\end{array}$ & $\begin{array}{l}\text { Incom- } \\
\text { plete } \\
\text { complete }\end{array}$ & Marked & $\begin{array}{l}\text { Both knees } \\
\text { and femoral } \\
\text { shafts }\end{array}$ & - & - & I9.10.67 & - & - & - \\
\hline 15. & N., G. & I 937 & 17.9.66 & $\begin{array}{l}\text { Skull } \\
\text { fracture }\end{array}$ & $\begin{array}{l}\text { Tetra- } \\
\text { paresia }\end{array}$ & $\begin{array}{l}\text { Incom- } \\
\text { plete }\end{array}$ & Moderate & Both hips & $\begin{array}{c}\text { December } 66 \\
\text { or } \\
\text { January } 67\end{array}$ & - & - & $\begin{array}{l}\text { R. hip: } \\
24.4 .68 \\
\text { L. hip: } \\
\text { I5.5.68 }\end{array}$ & $\begin{array}{l}\text { Pre-op.: } \\
\text { hip blocked in } \\
25^{\circ} \text { flex. } \\
\text { Pre-op.: } \\
\text { hip blocked in } \\
155^{\circ} \text { flex. }\end{array}$ & $\begin{array}{l}\text { 21 months: both hips } \\
\text { Flex./Ext:: } 80^{\circ} / 0^{\circ} \\
\text { Abd./Add.: } 15^{\circ} / 40^{\circ} \\
\text { IR/ER: } 15^{\circ} 40^{\circ} \\
\text { No recurrence of } \\
\text { POA } \\
\end{array}$ \\
\hline 16. & I., D. & 1952 & 30.7 .72 & Traumatic & $\begin{array}{l}\text { D5-D6 } \\
\text { bilat. }\end{array}$ & Complete & Slight & $\begin{array}{l}\text { Left femur } \\
\text { "Post- } \\
\text { traumatic" } \\
\text { POA deve- } \\
\text { loped at the } \\
\text { site where } \\
\text { 5i-m. injec- } \\
\text { tions were } \\
\text { given } \\
\end{array}$ & 28.8 .72 & 29.8 .72 & $4.9 .7^{2}$ & - & - & - \\
\hline 17. & L., I. & I9I 6 & 28.2 .70 & $\begin{array}{l}\text { Subarach- } \\
\text { noidal } \\
\text { hemorrhage }\end{array}$ & $\begin{array}{l}\text { Left } \\
\text { hemi- } \\
\text { plegia }\end{array}$ & - & Moderate & Left hip & - & $4 \cdot 5 \cdot 70$ & 30.6 .70 & - & - & - \\
\hline
\end{tabular}


TABle II (Case I)

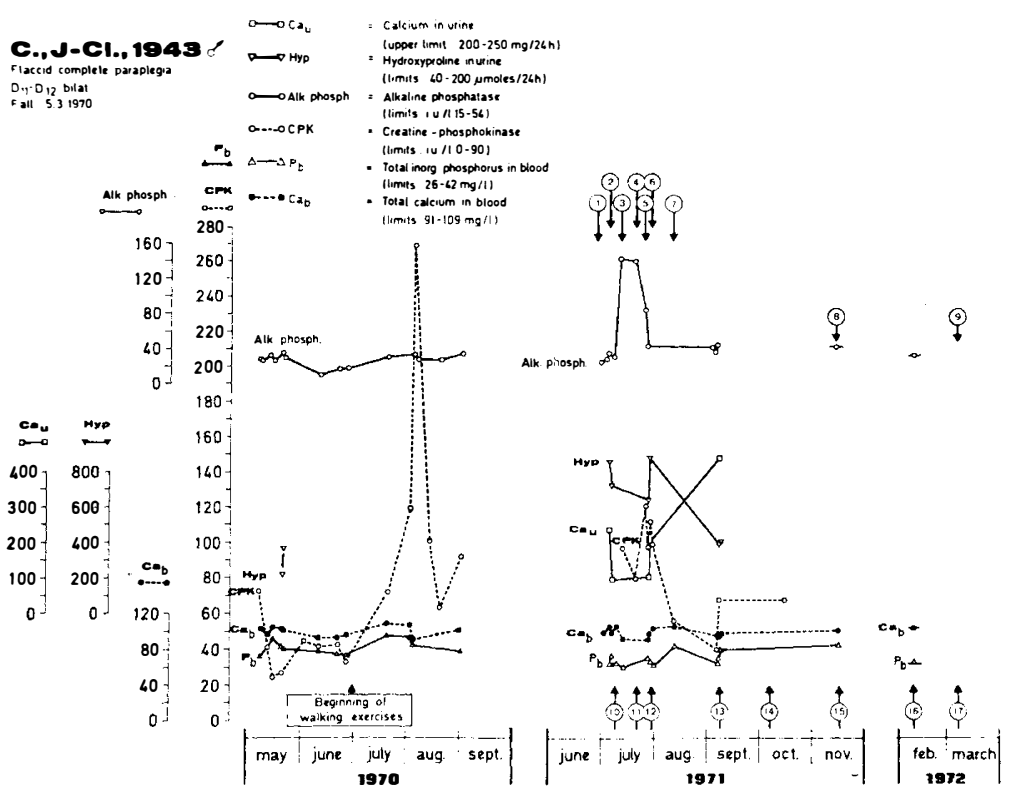

I. First clinical signs of POA at the left femur.

2. No visible POA on X-ray (see also fig. I, $a$ ).

3. First radiological appearance of POA (see also fig. I, $c$ ).

4. POA limits better defined.

5. Biopsy of POA, distal aspect.

6. No radiological change in the POA.

7. POA increased in size distally on X-ray.

8. No radiological change in POA.

9. Internal remodelling of POA on X-ray; no other change.

IO. Ist angiography (see also figs. $3 a$ and $b$ ).

I I. Ist ${ }^{87 \mathrm{~m}} \mathrm{Sr}$ scintigraphy-uptake ratio: $6 \cdot 0$.

12. 2nd angiography.

13. 2nd ${ }^{87 \mathrm{~m}} \mathrm{Sr}$ scintigraphy-uptake ratio: $4 \cdot 0$. 3rd angiography (see also fig. 3, c).

I4. 3 rd ${ }^{87 \mathrm{~m} S r}$ scintigraphy-uptake ratio: $3 \cdot 33$.

I5. $4^{\text {th }}{ }^{87 \mathrm{~m}} \mathrm{Sr}$ scintigraphy-uptake ratio: $3 \cdot 24$.

I6. 5 th ${ }^{87 \mathrm{~m}} \mathrm{Sr}$ scintigraphy-uptake ratio: $\mathrm{I} \cdot 96$.

17. 6 th ${ }^{87 \mathrm{~m}} \mathrm{Sr}$ scintigraphy一uptake ratio: $2 \cdot 47$.

The CPK elevation may be related to increased muscle activity caused by the beginning of walking exercises (Kief et al., 1972). 
TABLE III (Case 2)

\section{I.L., Ơ, 1937}

Complete spastic paraple -

gia $D_{6}$ bilat.

Traffic accident: 14.12.1971

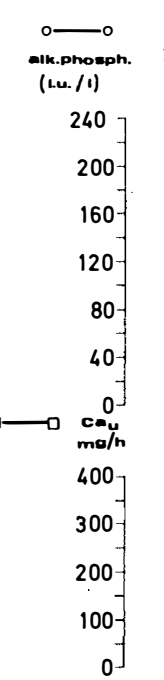

0

(1) X-ray of the pelvis: no POA

(10) $4^{\text {th }} 87 \mathrm{~m}_{\mathrm{s}}$ scintigraphy

(2) first clinical signs of $P O A$ at the left hip (ii) transurethral resection of the bladder neck

(3) $15187 m_{51}$ scintigraphy

$\begin{array}{ll}\text { first } x \text {-ray signs of POA } & \text { (1) } 5^{\text {th }} 87 \mathrm{~m}_{\mathrm{sr}} \text { scintigraphy }\end{array}$

(4) increase of POA at the left hip

(6) blopsy

(7) external sphincterotomy

(8) $2^{\text {rd } 87 \mathrm{~m}_{\mathrm{sr}} \text { scintigraphy }}$

begining or POA al he right hip

(15) $6^{\text {th }} 87 \mathrm{~m}_{\mathrm{Sr}}$ scintigraphy

(16) $7^{\text {th }} 87 \mathrm{~m}_{\mathrm{sr}}$ scintigraphy

(17) $X$ ray of the pelvis : statu quo

(B) development of massive POA

at both femoral shafts



(cro.

2607 ImJuRY

at both femoral shafts

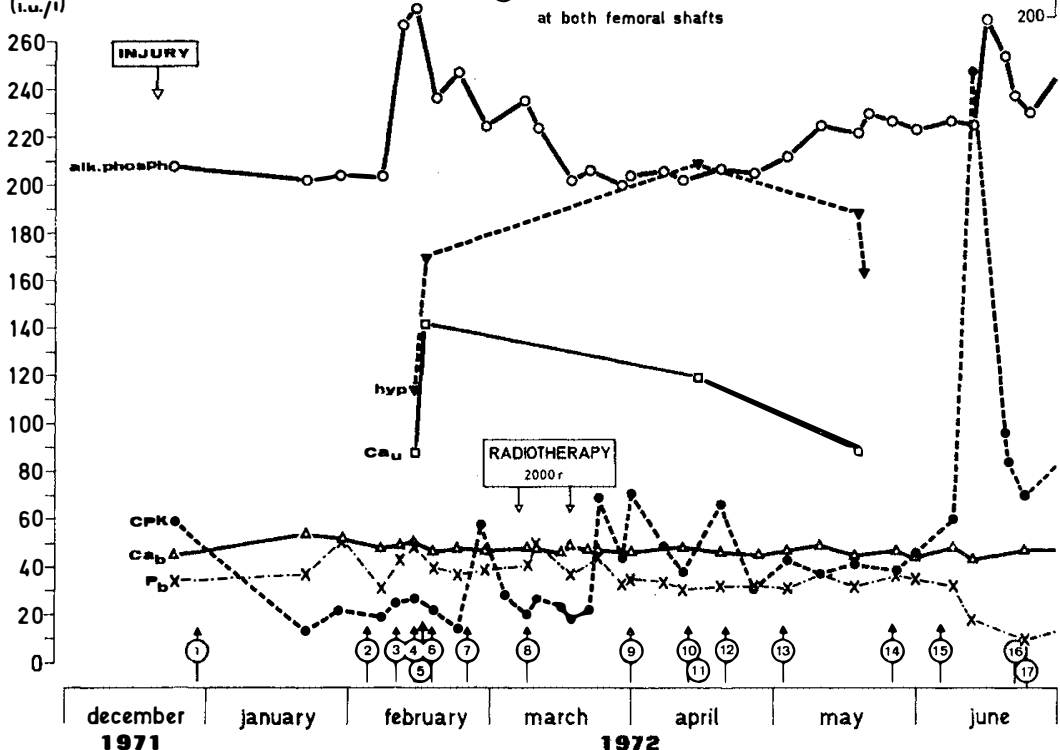

197

CPK: creatinephosphokinase (o-9o i.u./1).

$\mathrm{Ca}_{\mathrm{u}}$ : urine calcium (upper limit: $200-250 \mathrm{mg}$. $/ 24$ hours).

Hyp: urine hydroxyproline (407-200 $\mu$ moles/24 hours).

$\mathrm{P}_{\mathrm{b}}$ : total serum inorganic phosphorus $(26-42 \mathrm{mg} . / \mathrm{l})$
$\mathrm{Ca}_{\mathrm{b}}$ : total serum calcium (9I-IO9 $\left.\mathrm{mg} . / \mathrm{l}\right)$.

Alk. phosph.: alkaline phosphatase (I 5-54 i.u./1).

According to Kärcher (1972), a temporary CPK elevation could be caused by anti-inflammatory radiotherapy. 


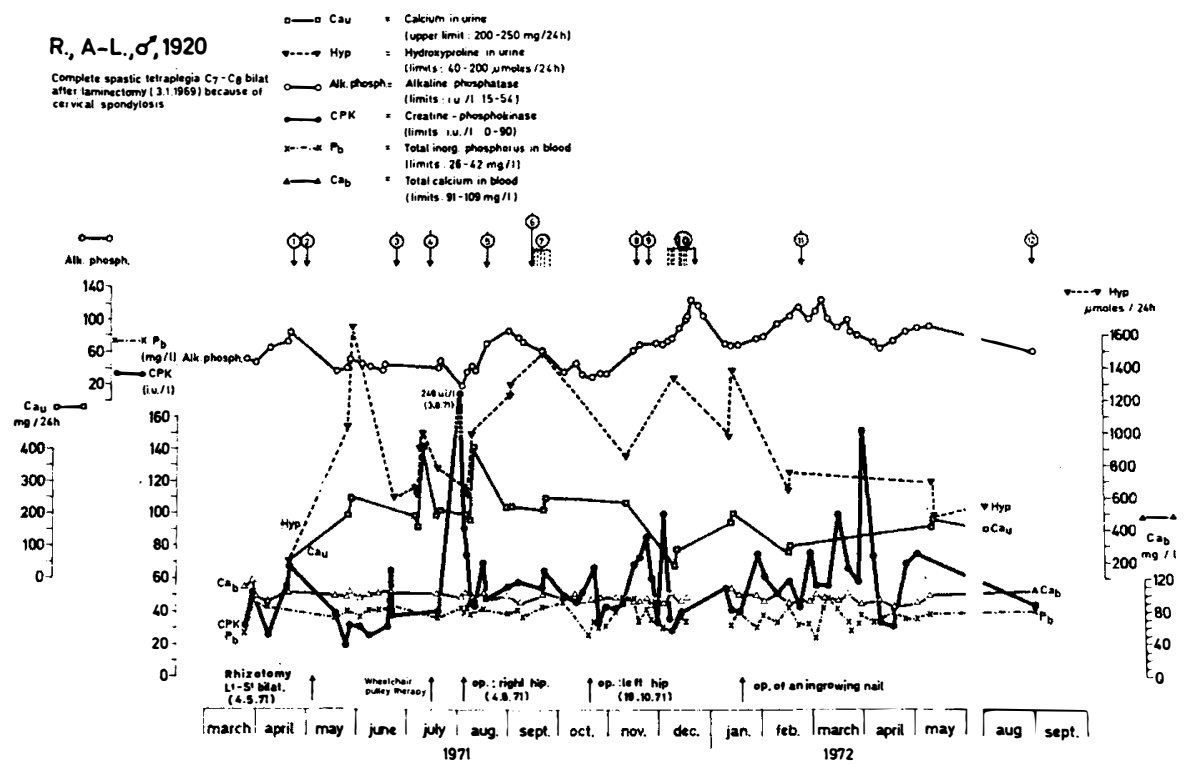
I. Ist angiography.
2. Ist ${ }^{85} \mathrm{Sr}$ scintigraphy.
3. 2nd angiography.
4. 2nd ${ }^{85} \mathrm{Sr}$ scintigraphy.
5. Recurrence of the right POA.
6. $3 \mathrm{rd}^{85} \mathrm{Sr}$ scintigraphy.

7. Radiotherapy (I $500 \mathrm{r}$ to the right POA).

8. 3rd angiography.

9. Recurrence of the left POA.

Io. Radiotherapy (I600 $r$ to the left POA.)

I I. 4 th ${ }^{85} \mathrm{Sr}$ scintigraphy.

12. 5 th ${ }^{85} \mathrm{Sr}$ scintigraphy.

\section{B. Angiographic Studies of the Lower Limbs}

Materials and Methods. Eighty-six arteriographies were performed on 43 patients, according to the technique described by Seldinger, using a $45 \mathrm{~cm}$. green KIFA (Fack, Stockholm, Sweden) catheter and injecting $60 \mathrm{~cm} .{ }^{3}$ of Na and methylglycamine salts of amidotrizoate ${ }^{2}\left(40 \mathrm{~cm}^{3}\right.$ of 76 per cent. and $20 \mathrm{~cm}^{3}$ of a 60 per cent. solution), over a span of 4 seconds, at a pressure of 5 atmospheres. Studies were performed on an extra-large field seriograph $(120 \mathrm{~cm} . \times 30 \mathrm{~cm}$.), or, on an AOT seriograph $(35 \mathrm{~cm} . \times 35 \mathrm{~cm}$.) (Elema-Schönander, Solna, Sweden). Film times were calculated from mid-injection. No complications were experienced as a result of this procedure. Occasionally, serial catheterisations were difficult, and in some cases, we were forced to abandon the procedure because of being unable to pass a catheter through the inevitable scar tissue, consequent to haematomata due to previous catheterisation.

I. Patients Without POA. One of the main questions to be answered is: does a cord lesion play a role in the angiographic modifications?

Our observations are based on the interpretations of 50 angiograms in 26 patients: Io patients with a single procedure: nine patients with two; six patients with three, and one patient with four procedures.

$$
2 \text { Urografin }{ }^{(R)} \text {, Schering, Berlin, Germany }
$$


TABLE V (Case I2)



Normal limits in parenthesis.

Hyp: urine hydroxyproline (IO-40 mg./24 hours.)

Alk. phosph.: alkaline phosphatase (IO-40 i.u./1).

$\mathrm{Ca}_{\mathrm{u}}$ : urine calcium (upper limit: $200-250 \mathrm{mg} . / 24$ hours).

$\mathrm{Ca}_{\mathrm{b}}$ : total serum calcium (9I-109 mg./1).

$P_{b}$ : total serum inorganic phosphorus $(26-42 \mathrm{mg} . / 1)$.

In a first group composed of four patients, angiography, between the 48 th and the I33rd day post-cord-trauma, showed that early venous return may occur, and that this anomaly regresses, and disappears during the months following, i.e., 5 to I7 months, post-injury.

In a second group of six patients with early angiograms from the 5 th to the 40 th day post-trauma, we found an absence of early venous return, only to find it appearing later, in the chronic stages of cord trauma, usually from 3-5 months post-trauma. Here also, we found a return of angiographic signs to normal after a period of IO-I5 months.

Finally, a third group was constituted of three patients whose angiographies never demonstrated any anomaly, either early (5th, I2th, I6th days), or late (5th, 7 th, 7 th months). These three patients had in common, the ability to walk without assistance.

One of these three patients had a bilateral flaccid paralysis at the level of $\mathrm{L}_{3}-\mathrm{L}_{4}$, and walked with bilateral braces to prevent drop-foot: his angiograms were normal on the 5 th, and $213^{\text {th }}$ days post-trauma.

The second of these patients had bilateral, spastic tetraparesia at $\mathrm{C}_{7}$, and walked with a single drop-foot brace: his angiograms were normal on the 12 th and I 54 th days post-trauma. 
The final patient was neurologically normal, but had presented a transitory paraparesis after a fracture of $\mathrm{LI}_{\mathrm{I}}$ his angiograms were normal on the I6th, I I2th, and 158 th days post-trauma.


FIG. 2 (Case 5)

A, X-ray of the pelvis 9 weeks after clinical onset of POA. B, X-ray of the pelvis 20 weeks af ter clinical onset of POA. Decrease in size of the POA at the left lesser trochanter. No conclusion can be drawn from the appearance of the POA at the right lesser trochanter due to the difference in X-ray incidence.

Comparing the four patients of the first group, with the six patients of the second group, it was found that both contained cases of complete and incomplete lesions; spastic and flaccid. Two observations may be made in comparing these two groups: 
(a) The first angiography in each patient of the first group took place much later in the evolution of the lesion, average 88 days (range: 48-I33 days), than in the second group, average 20 days (average: 5-40 days). This difference alone is sufficient to explain the presence of an early venous return in one group only.

(b) The last angiography, towards the 15 th month post-trauma, of each of the patients of the first group, showed a regression of the pathological signs first seen: reduction of the increased vascularity of the hip area, with regression of the early venous return and arteriovenous shunts. Two patients of the first group had entirely normal angiograms at the 15 th and the I 7 th months.

2. Patients With POA. Although arteriography provides interesting information about the modifications of vascularisation in the area of POA formation and at a distance from it, the interpretation of this information poses two problems:

(i) Are the modifications observed a part of the aetiology, or a consequence of the POA?

(ii) Are the modifications observed a measure of the completion and maturity of the ectopic ossification?

\section{RESULTS AND DISCUSSION}

The findings of this study are based on the interpretation of 36 angiographies in 17 patients: six patients with a single arteriography; six patients with two examinations; three patients with three examinations, and two patients with four and five examinations; respectively. From one isolated examination we were able to draw little in the way of valid conclusions. Only a dynamic picture obtained by serial procedures in each patient would enable the angiographic evolution of the POA to be understood. This itself being a function of the time at which the examination was performed, thus a function of the maturity of the ectopic ossification process. We understand why Hutcheson et al. (1972) with a single angiography in their reported patient were unable to demonstrate any arteriovenous shunting.

Two patients (cases 6 and 7) underwent arteriography prior to the onset of clinical signs of POA; one, the Ist day post-trauma (who later developed bilateral POA at the medial femoral condyles) and the other, 4 days post-trauma (who later developed bilateral POA at the anterior superior iliac spines).

In the first of the above cases, arteriography revealed bilateral arterial vasoplegia $^{3}$, predominantly left-sided, with early venous return in the left foot at I6 seconds, and a left superficial femoral vein visualised at I I seconds.

Angiography in the second case was within normal limits except for a slight, bilateral vasoplegia.

In cases of POA, the early venous return is due to opening of arteriovenous shunts; the increase in arterial caliber is due to increased circulatory dynamics. In acute-post-traumatic vasoplegia, arterial dilatation results from paralysis of the medullary vasomotor centres. In POA, arterial dilatation is confined to the diseased region, while in vasoplegia, the phenomenon is generalised.

Of 12 patients who underwent angiographic investigations between the first and the I6th day, post-trauma, five showed some degree of vasoplegia; two of whom subsequently developed POA.

${ }^{3}$ By vasoplegia, we understand an early distal opacification of arteries whose caliber is increased, with, or without early venous return (with normal venous $\mathrm{O}_{2}$ saturation in the latter). 
i. Patients With Chronic POA. In cases of POA of several months' or years' duration, there may be no signs of arterial modification, either ipsilateral, or controlateral (cases 3 and 8). Early venous return may be either absent (cases 3 and 8 ), or present, in association with local increased vascularity (cases 9 and Io, POA of 2 years' duration at the time of examination; case II, POA of 3 years' duration).

A review of those of cases studied which came to operation shows that the persistance, or absence of early venous return is not a valid indication of the degree of maturity of the ectopic ossification process. One patient (case 3), whose POA had been clinically present for 2 years prior to angiography, had neither increased vascularity, nor early venous return; however, this patient presented a major postoperative recurrence of his POA.

On the other hand, another patient (case I0), whose bilateral hip POA were also 2 years old at initial angiography, showed bilateral early venous return. This patient underwent resection of her left hip POA; 23 months after her first angiography, another angiography showed persistance of intense early venous return on the right. The following day she underwent resection of her right POA; 9 months post-resection, there had been no sign of recurrence.

ii. Patients With Acute POA. Our angiographic studies, in cases of evolving POA, revealed acceleration of arteriovenous transit, increased vascularisation (sometimes considerable), dilatation of some vessels, e.g. the circumflex femoral artery in cases of POA of the hip region, and an early venous return, evidence of the presence of massive arteriovenous shunting (cases I and 2; fig. 3, $a-c$; fig. 4, a). Repeat angiographic studies in one case of developing POA (case 2), revealed amputation of a vessel whose course terminated in the ectopic bone formation (fig. $4, b, c$ ). At operation, we were able to complement this observation in two other patients (cases IO and 15), where vessels were found to penetrate the POA mass, although no vascular involvement with the bone mass was seen in the preoperative angiograms. This seems to indicate that, in some cases, the POA may be constituted around pre-existing vessels (see p. 63).

As the ectopic bone matures, the pathological angiographic findings regress, in particular, the vasodilatation and local increased vascularity, without, however, necessarily returning to normal. A considerable degree of early venous return may persist.

\section{CONCLUSIONS}

Interpretation of post-trauma angiography in patients with, and without POA, has lead to the following observations:

\section{Patients Without POA}

(a) Demonstration of local increased vascularity, about the hip especially, and of early venous return, depends on the interval between the trauma and the angiography, probably among other factors, which remain to be determined. In general, angiographic signs do not appear in the acute phase (the first 3 weeks) of cord trauma, but appear after 2-3 months.

(b) All pathological angiographic signs regress with time and disappear towards the I 5 th month post-trauma.

(c) The foregoing observations are found to be independent of the level of the cord lesion and of the spasticity or flaccidity of the lesion. Angiographic signs do, 



FIG. 3 (Case I)

A, Angiography 9 days after clinical onset of POA. $\mathrm{X}$-ray taken at 3 seconds. Marked increase in vascularity at the level of the left femoral POA. B, Angiography 9 days after clinical onset. $\mathrm{X}$-ray taken at 6 seconds. Intense early venous return at the level of the left lateral circumflex vein, a tributary of the deep femoral vein. C, Angiography 2 months later. X-ray taken at 6 seconds. Persistence of increased vascularity around the left femoral neck; disappearance, however, of early venous return.

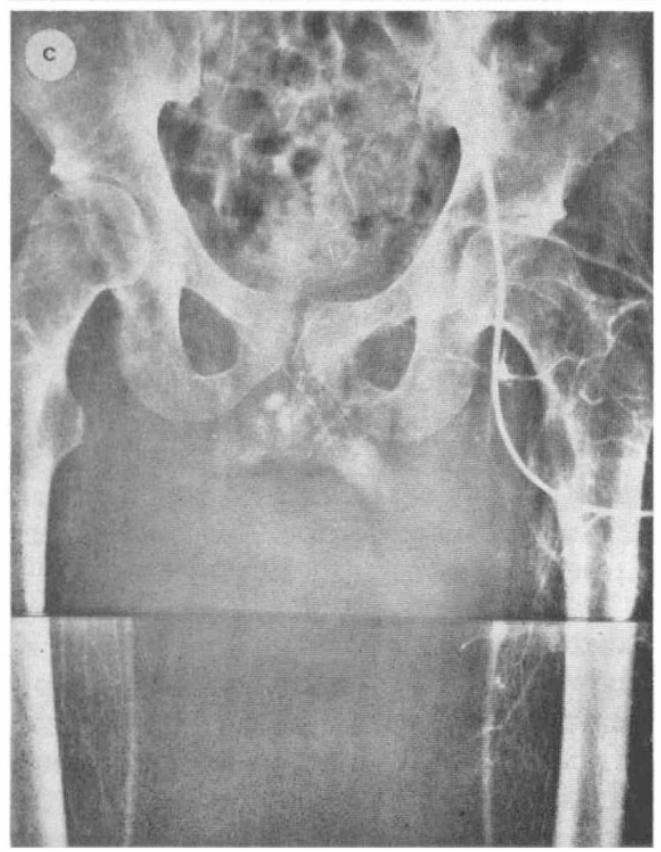

I I / I - D 
however, seem to depend upon the extent of the lesion. Only those patients with a lesion sufficiently incomplete to permit almost totally unassisted walking had unperturbed lower limb angiography, both in the acute and chronic stages of their cord lesion. It may be concluded from this, that the degree of injury to the sympathetic system is probably responsible for the angiographic modifications seen;


FIG. 4 (Case 2)

A, Angiography II days postclinical onset of POA. X-ray taken at 3 seconds. Increased vascularity and considerable dilatation of the left femoral circumflex artery at the level of the POA (arrow). B, Angiography 99 days later. X-ray taken at 3 seconds. Decreased hypervascularity and diminished diameter of the left femoral circumflex artery at the level of the POA. The descending branch of the left lateral circumflex artery can be seen to be included in the POA (arrow). C, Angiography 24 weeks later. X-ray taken at 3 seconds. The left femoral circumflex artery shows a tortuous and irregular course, modified by the POA (arrow).

corroborating the results of Claude Bernard in I859! Grant (I929-3I) has shown that the stimulation of the peripheral end of the cut cervical sympathetic nerve provoked the closure of arteriovenous anastomosis, whereas interruption of the stimulation caused them to re-occur.

(d) Since none of the patients in the three groups mentioned ever developed POA, it may be concluded that the presence of early venous return is not a factor in the development of POA, but may well be secondary, confirming the hypothesis of Bidart and Maury (1970). 


\section{Patients With POA}

(a) The onset of POA is accompanied by angiographic modifications, including: local increased vascularity, increased arterial diameter and early venous return. In general, these signs regress as the POA ages. Angiographic signs may persist for years (case II). One may not, however, conclude from the persistance of angiographical signs, that the POA is not yet mature.

(b) Normalisation of an initially pathological angiogram does not of necessity signify that the maturation of the ectopic bone formation is complete and that the POA is stabilised.

(c) A single, isolated angiogram is of little value. The introduction of a dynamic element by comparison of serial angiograms, makes it possible to follow the evolution of the angiographic modifications as the POA ages.

(d) The evolution of the angiographic modifications does not, however, permit interpretation as to the activity or maturity of the POA process.

(e) The angiographic modifications associated with POA are secondary to the $P O A$ and not a cause.

( $f$ ) Angiography is not a useful parameter for deciding when a POA may be operated with least risk of recurrence.

\section{Arterial and Venous Blood Gases, Serum Enzymes and Electrolytes}

I. $\mathrm{O}_{2}$ Saturation, $\mathrm{pH}, \mathrm{CO}_{2}$, and $\mathrm{pCO}_{2}$. In general, cases of POA in evolution, laboratory values, above all, $\mathrm{O}_{2}, \mathrm{pH}, \mathrm{pCO}_{2}$, and alkaline phosphatase, evolve in the same direction as the angiographic modifications, thus, corroborating the diagnosis of both arteriovenous shunts and dynamic bone rearrangement.

In cases of POA of several months' duration, arteriovenous shunting was found, as shown by elevated venous $\mathrm{O}_{2}$ saturation, without necessarily finding early venous return at angiography. This apparent contradiction may be explained by the fact that angiography provides a differential image of the vascular structures of the lower limb and the hip region, whereas blood gases reflect the ensemble of phenomena occurring in the lower limb and pelvis. In addition, depending on its position, the catheter may be positioned near a relatively less pathologic venous channel, although in the proximity of the POA lesion.

It appears likely that it is the progressive decrease, over the course of time, of the pathological laboratory values which may allow one to conclude that the evolution of the POA is proceeding towards maturity. Persisting pathological laboratory values, however, do not indicate that the process has not attained stability. In two patients (cases 8 and Io), a few days prior the operative resection of their POA, ipsilateral venous $\mathrm{O}_{2}$ saturation of 80 per cent. was found in one and 84 per cent. in the other (normal: 75 per cent.). To date, 29 months in case 8 and 9 months in case Io there has been no recurrence.

Bénassy et al. (1963), reported in nine of their patients, a marked arterialisation of lower limb venous blood in contrast to a relatively important desaturation of upper limb venous blood, probably due to a compensatory mechanism. The average value of venous $\mathrm{O}_{2}$ saturation for the upper limb was 33.8 per cent. (with a lower limit of 19 per cent.), while the lower limb average was 75.2 per cent., giving a difference of $4 \mathrm{I} \cdot 4$ per cent. Although our sample was small (five upper and lower limb venous $\mathrm{O}_{2}$ saturation determinations in four patients), our results (Table VI) do not confirm those of Bénassy et al. (1963). 


\section{TABLE VI}

Comparative $\mathrm{O}_{2}$ saturation in femoral and subclavian veins.

\begin{tabular}{|c|c|c|c|c|c|c|c|}
\hline \multirow[t]{2}{*}{ Diagnostic } & \multirow[t]{2}{*}{$\begin{array}{l}\text { Date of } \\
\text { lesion }\end{array}$} & \multirow[t]{2}{*}{$\begin{array}{c}\text { Date of } \\
\text { examination }\end{array}$} & \multirow[t]{2}{*}{$\begin{array}{c}\mathrm{O}_{2} \text { sat. in } \% \\
\text { Femoral } \\
\text { artery }\end{array}$} & \multicolumn{2}{|c|}{$\begin{array}{c}\mathrm{O}_{2} \text { sat. in } \% \\
\text { Femoral } \\
\text { vein }\end{array}$} & \multicolumn{2}{|c|}{$\begin{array}{c}\mathrm{O}_{2} \text { sat. in } \% \\
\text { vein }\end{array}$} \\
\hline & & & & $\mathbf{R}$ & $\mathrm{L}$ & $\mathbf{R}$ & $\mathrm{L}$ \\
\hline $\begin{array}{l}\text { Pf., R. } \text { o }^{1} 1950 \\
\text { Traumatic complete } \\
\text { flaccid tetraplegia } \\
\mathrm{C}_{3}-\mathrm{C}_{4} \text { bilat. (spinal } \\
\text { shock.) } \\
\text { Note: No POA. }\end{array}$ & $25.10 .7 \mathrm{I}$ & 28.10.7I & 94 & $73 \cdot 5$ & 73 & 77 & - \\
\hline 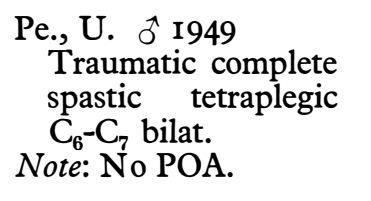 & I3.9.7I & I6.II.7I & 96,5 & 77 & 77 & - & $6 \mathrm{I}, 5$ \\
\hline $\begin{array}{l}\text { B., P. } 0 \text { I } 1945 \\
\text { See case } 9 \text { : left } \\
\text { hemiplegia. } \\
\text { Note: POA left hip, left } \\
\text { shoulder and right hip. }\end{array}$ & 7.10.70 & 22.6 .72 & 98 & 79 & 84 & 67,5 & 67,5 \\
\hline $\begin{array}{l}\text { D., M. P I } 953 \\
\text { See case ro: Guillain- } \\
\text { Barré. } \\
\text { Note: POA at both hips. }\end{array}$ & 19.2.68 & 9.2 .72 & 95,5 & 73 & - & 64,5 & - \\
\hline
\end{tabular}

\section{CONCLUSIONS}

(i) The results of arteriovenous blood gases correspond in general to the angiographic modifications observed. bone.

(ii) These values are of no use in judging the degree of maturity of the ectopic

2. Alkaline Phosphatase. In the absence of any hepatic pathology, the persistance of elevated serum alkaline phosphatase is a sign of growing bone. By a method of separating the iso-enzymes of the serum alkaline phosphatase (hepatic, bone, intestinal and biliary fractions), it was confirmed, as stated by Couvée (I97I), that the bone fraction is responsible for the elevated alkaline phosphatase observed in our patients (fig. 5). Shifrin (1970) showed that there was no relationship between the metabolism of lamellar bone and the alkaline phosphatase value; however, it seems probable that the elevation of this enzyme reflects an increase in the formation of fibrillar bone. 


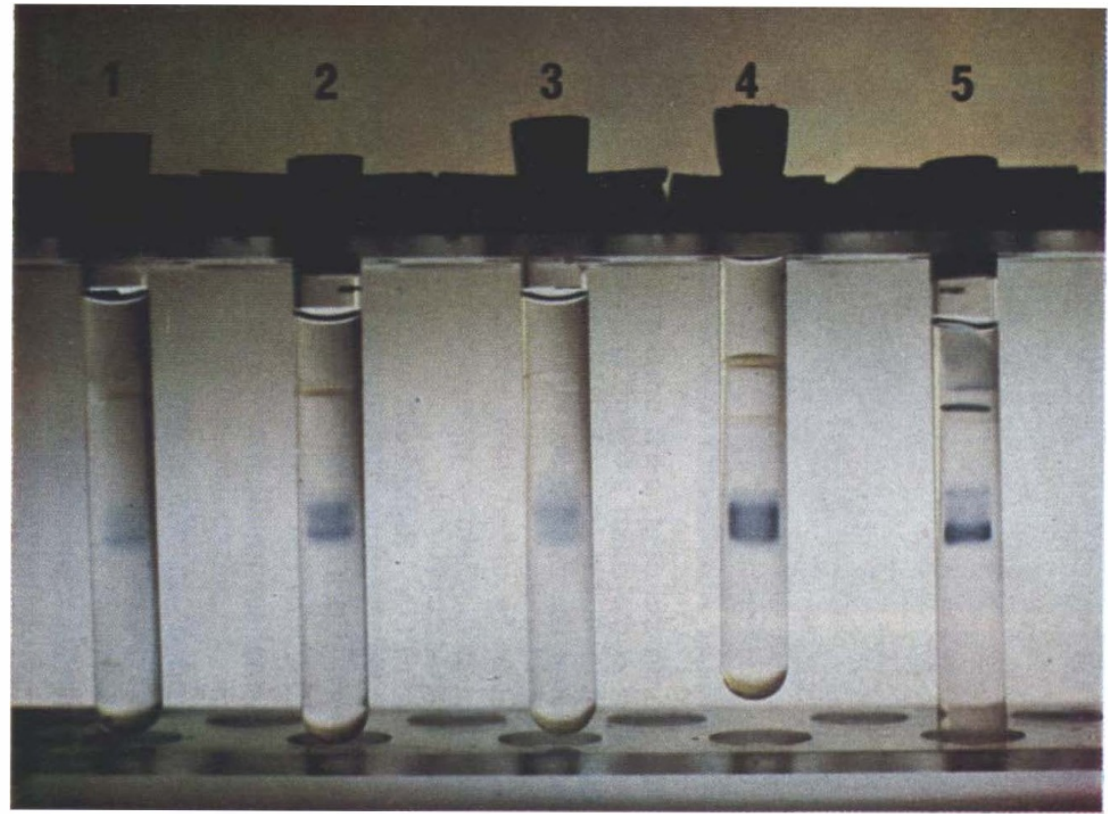

FIG. 5

I: Normal serum: only the liver and bone fractions appear; the liver fraction more marked than the bone fraction.

2: Example of distinct elevation of the bone fraction which appears very thick; slight elevation of the hepatic fraction.

3: POA case 2: the bone iso-enzyme is more marked than in the control and is slightly diffuse. The hepatic fraction remains normal.

4: Hepatic and bony metastases: large increase of the liver and bone isophosphatases which become inseparable.

5: Hepatic metastases: large increase of the liver fraction (intra-hepatic obstruc-

tion). The bone iso-enzyme remains normal; above a well-defined intestinal fraction appears. At the limit between the two gels, an intense biliary fraction is seen (extra-hepatic obstruction).

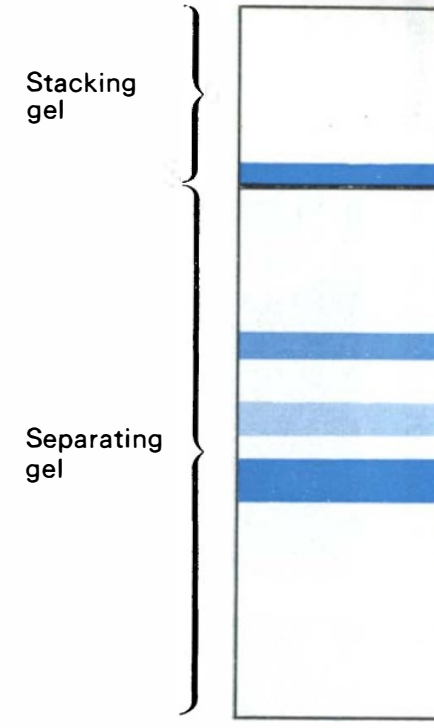

Biliary fraction

Intestinal fraction

Bone fraction

Liver fraction

Serum iso-alkaline phosphatase electrophoresis on polyacryamide gel. 
Although the elevated alkaline phosphatase seems to indicate active bone metabolism, normal levels of the enzyme do not necessarily indicate stabilisation of a pathological process. The two patients (cases 3 and 4 ) who had recurrences of

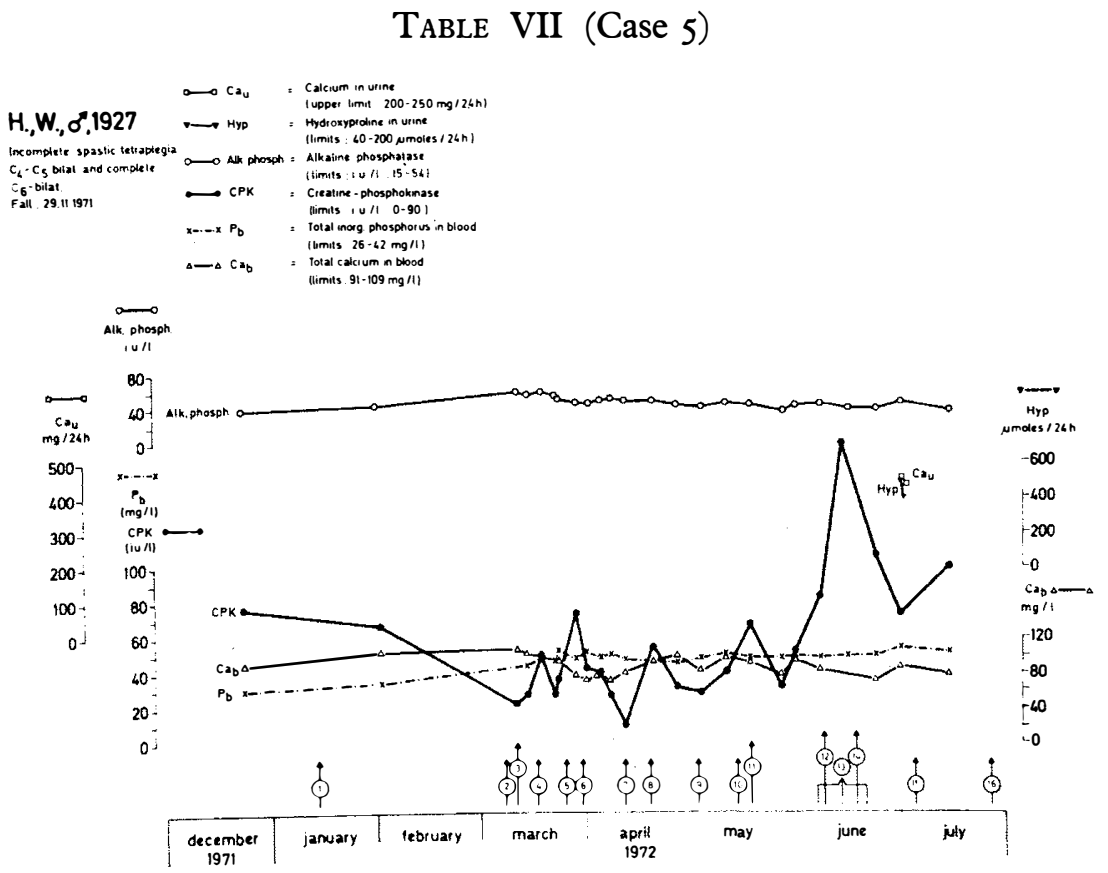

I. Ist ${ }^{87 \mathrm{~m}} \mathrm{Sr}$ scintigraphy: normal uptake ratio.

2. 2nd ${ }^{87 \mathrm{~m} S r}$ scintigraphy - uptake ratio on the right: 3.9 ; uptake ratio on the left: 3.9 .

3. X-ray of the pelvis: POA at both lesser trochanters.

4. Ist angiography.

5. X-ray of the pelvis: no change in the POA.

6. 3 rd ${ }^{87 m}$ Sr scintigraphy - uptake ratio on the right: 2.97 ; uptake ratio on the left: 2.90 .

7. th $^{87 \mathrm{~m} S r}$ scintigraphy-uptake ratio on the right: 2.63 ; uptake ratio on the left: 2.54 .

8. X-ray of the pelvis: POA unchanged.

9. 5 th ${ }^{87 \mathrm{~m}} \mathrm{Sr}$ scintigraphy - uptake ratio on the right: 2.66 ; uptake ratio on the left: 2.50 .

Io. X-ray of the pelvis: POA unchanged.

II. 2nd angiography.

12. 6th ${ }^{87 \mathrm{~m}} \mathrm{Sr}$ scintigraphy - uptake ratio on the right: $2 \cdot 37$; uptake ratio on the left: $\mathbf{2 \cdot 2 3}$.

13. alcoholisation of peripheral nerves (spasticity).

14. X-ray of the pelvis: decrease of the left POA. Right POA unchanged.

15. 7 th ${ }^{87 \mathrm{~m}} \mathrm{Sr}$ scintigraphy-uptake ratio on the right: $2 \cdot$ IO; uptake ratio on the left: I.5I.

I6. X-ray of the pelvis: further decrease of the left POA, no change of the right POA.

POA after operative resection had normal serum alkaline phosphatase for Io and I I weeks prior to surgery (Table IV).

In the two patients (cases I and 2) in whom the formation of POA was observed from the very onset of clinical signs, before the appearance of radiological signs, as well as in a similar third case (case 12), diagnosed just after the onset of radiological signs, it was noticed that elevation of the serum alkaline phosphatase and the appearance of radiologic signs of the lesion followed within a few days. 
Nechwatal (1972), found to the contrary that the elevation of alkaline phosphatase preceded the first X-ray signs by about 2 weeks. In addition, there seems to be a relationship between the size of the POA and the level of the alkaline phosphatase. A lesion of only a few centimeters in diameter, for example, rarely gives rise to clinical symptoms or biochemical signs (Table VII; fig. 2, $a, b$; case 5). Likewise, there seems to be a direct relationship between the size of the POA and the duration of the alkaline phosphatase elevation. With a large ectopic bone formation (cases 2 and I2; Tables III and V), the alkaline phosphatase may remain elevated for weeks or months, before returning to normal (7 months in case I2; five months, so far, in
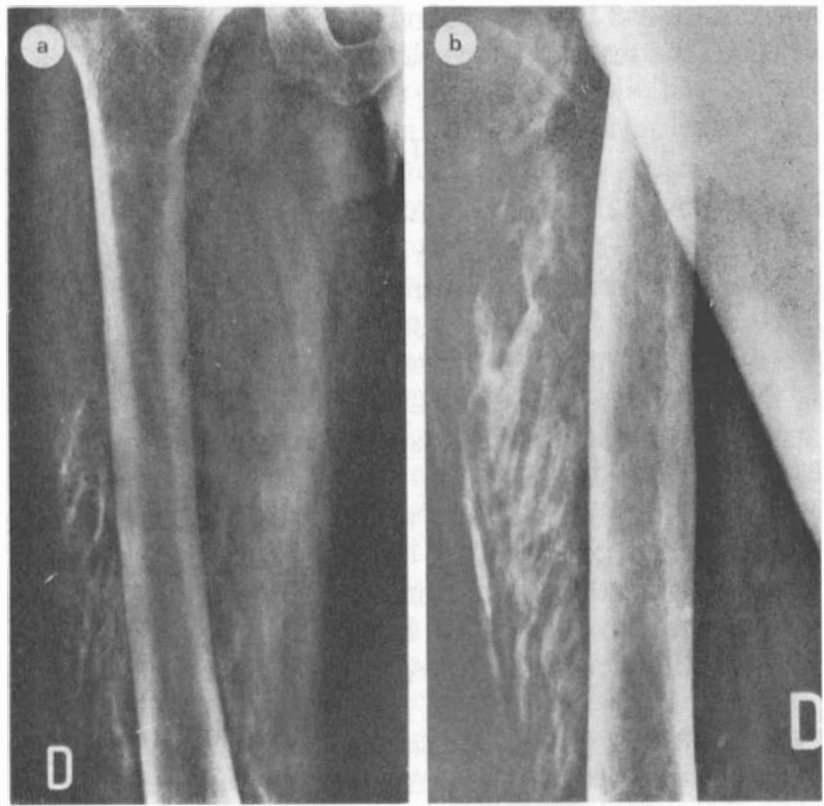

Fig. 6 (Case 2)

A, AP X-ray of the right femur, one month after clinical onset of the POA. As a possible traumatic factor in the onset of the POA, it may be noted that the patient was very brisk with his legs, striking his thighs in order to change their position in his bed or wheelchair. B, Lateral view of the right femur at the same time. The POA lies anterior (left) to the femur.

case 2 which is still in evolution). In smaller POA formations the duration of the alkaline phosphatase elevation may be much shorter (I4 days in case I) although the levels attained may be quite high: I45 international units/litre in case I (Table II).

In spite of normal alkaline phosphatase levels, other parameters, such as the bone scan, may reveal that the ossification process has yet to stabilise, confirming that the serum alkaline phosphatase levels are of relative value only, in judging the evolution of the POA lesion.

During POA evolution it was observed that the alkaline phosphatase levels descend to near normal. Sometimes this phase of diminishing alkaline phosphatase levels may be followed by a second elevation, which the authors believe represents 
an extension of the initial process and/or the onset of a new POA lesion (Table III). In such cases of secondary alkaline phosphatase elevations, there is a close correlation between the alkaline phosphatase level and the evolution of the X-ray image (fig. 6, $a, b)$. Depending on the point in the evolution of the POA lesions at which the serum alkaline phosphatase is determined, it is not surprising to find normal enzyme levels. As Furman et al. (1970) pointed out, this probably explains why most authors did not find elevated serum alkaline phosphatase in their patients, especially since, in most cases, only one or two spot determinations were performed during the course of the lesion. It should be added at this point that the Swedish kinetic recording apparatus (Reaction Weight Analyser No. 8600) ${ }^{4}$ for serum alkaline phosphatase determinations ${ }^{5}$ in international units/litre uses a more sensitive and exact technique than the methods of King-Armstrong, Bodansky, and BesseyLowry.

\section{CONCLUSIONS}

(i) Elevation of the alkaline phosphatase is a sign of the presence of growing bone, a contra-indication to POA surgery.

(ii) Contrary to the opinion of Furman et al., (1970), normalisation of the alkaline phosphatase does not, in itself, constitute adequate proof of the stabilisation of the osteogenic process, even in presence of stable X-ray images over a period of time.

(iii) During the acute phase of the POA process, there is a correlation between $\mathrm{X}$-ray, angiography, serum alkaline phosphatase and degree of evolution of the disease process.

(iv) In the chronic phase of POA, there is no relationship between X-ray, angiography, serum alkaline phosphatase and maturity of the ectopic bone.

(v) Infrequent, isolated determinations of the serum alkaline phosphatase are of no use in following the evolution of POA. As for angiography, the dynamic picture produced by serial determinations gives a better idea of the status of the lesion.

3. Creatinephosphokinase (CPK). In two (cases I and 2), of the five patients with acute POA (cases I, 2, 5, 6, I6), it was found that elevation of the serum CPK followed that of the alkaline phosphatase, with the bone scans showing markedly increased uptake (Tables II and III). Microscopic examination of open biopsies of the POA bone in these cases showed muscular fibres involved in the ectopic bone mass. We hypothesise that the presence of elevated serum CPK values suggests the involvement of muscular tissue in the formation of the POA, since it is known that the concentration of $\mathrm{CPK}$ is high in striated muscle tissue.

In two other cases (cases 5 and I6), one bilateral POA at the level of the lesser trochanters, the other, one POA at the anterior aspect of the thigh, there was only a slight elevation of the alkaline phosphatase, without elevation of the CPK, in spite of a markedly increased uptake of ${ }^{87 \mathrm{~m}} \mathrm{Sr}$ (Table VII; case 5).

In the last case, a very limited bilateral POA at the medial femoral condyle (case 6), there was no elevation of the alkaline phosphatase, but the ${ }^{87 \mathrm{~m}} \mathrm{Sr}$ uptake was pathologic. At no time during the observation was the CPK found to be elevated (period of 4 months). Microscopic examination of the open biopsy performed 3 weeks after the onset of clinical signs, showed absence of any muscular

${ }^{4}$ LKB, Stockholm, Sweden

5 Geneva Cantonal Hospital, Central Laboratories, Dr. M. Roth, Director; Enzyme Division, Mr. C. Rosenbusch. 
fibres. It is likely that in these cases, with no CPK elevation, there was little or no muscular participation at all in the disease process.

\section{CONCLUSION}

Determination of serum CPK in five cases of acute POA suggests that elevation of this enzyme signifies participation of striated muscular tissue in the developing POA mass. This observation is supported by the conclusion of Welch and Goldberg (1972).

4. Urine Hydroxyproline (Hyp) and Calcium. The urine Hyp is known to reflect the metabolic activity of connective tissue. The exact role of the urine Hyp as an indication of incipient POA remains to be determined. The studies of Bénassy and Combelles (I97I), of Chantraine (I97I) and of Klein et al. (I966) have shown that there is an elevation of urine Hyp in para- and tetraplegia. This elevation may persist for as long as 24 months, and more, after the onset of the cord lesion.

Rossier et al. (unpublished data) have come to a like conclusion, after the study of 32 para- and tetraplegics from the acute through the chronic phases of their disease.

Urine Hyp values ranging from I 50-200 mg./24 hours (normal: $10-40 \mathrm{mg} . / 24$ hours) were frequently found in patients at the acute phase of cord disease, with no POA. These values are quite close to those found in patients with recent cord lesions (first 3-4 months) presenting an evolving POA (Tables II and V). Occasionally, even greater elevations were found, of the order of I200-I $400 \mu$ moles/24 hours, (six to seven times the maximum value indicated by Zender (I972); (Table III). Thus, in the case of a POA appearing early in the course of a cord injury (most POA develop within the first 2-4 months of the spinal lesion), it becomes difficult to separate the influence of the spinal cord injury from that of the POA itself.

Urine Hyp values were found, from this study to follow other laboratory values, in particular, the serum alkaline phosphatase, thus having the same significance. Chantraine (I97I) states 'there is no correlation [of urine Hyp] with associated pathological status such as fracture or para-articular osteopathy', the reason probably being that elevated urine Hyp early in the course of the cord lesion coincides with the formation of POA and may mask any component of Hyp elevation due to the POA process. If the elevation occurs later, it may be missed entirely and the POA may remain both chemically and clinically silent (Chantraine, in press).

In agreement with Bénassy and Combelles (I97I), we can confirm the finding that the evolution of the serum alkaline phosphatase and the urine Hyp of ten parallels the evolution of the POA process. It has also been shown by Lejeune et al. (1972) that urine Hyp was significantly related to the level of the serum alkaline phosphatase.

Our observations did not permit us to conclude from a normalisation of serum alkaline phosphatase or urine Hyp, that the POA bone had reached maturity. One of our cases (case 4) who had a post-operative recurrence, had a normal preoperative Hyp ( 44.6 and $52 \mathrm{mg}$. $/ 24$ hours). Her spinal cord lesion was 12 months old. Conversely, high Hyp levels do not necessarily indicate that the POA bone growth has not yet stabilised. Although the pre-operative Hyp in case I3 was II 2 and II $4 \mathrm{mg} . / 24$ hours, there was no recurrence. However, this patient's lesion was only 6 months old.

As reported by Chantraine (I97I) and Klein et al. (1966), the urine calcium levels in general paralleled the urine Hyp.

$$
\text { II } / \mathrm{I}-\mathrm{E}
$$



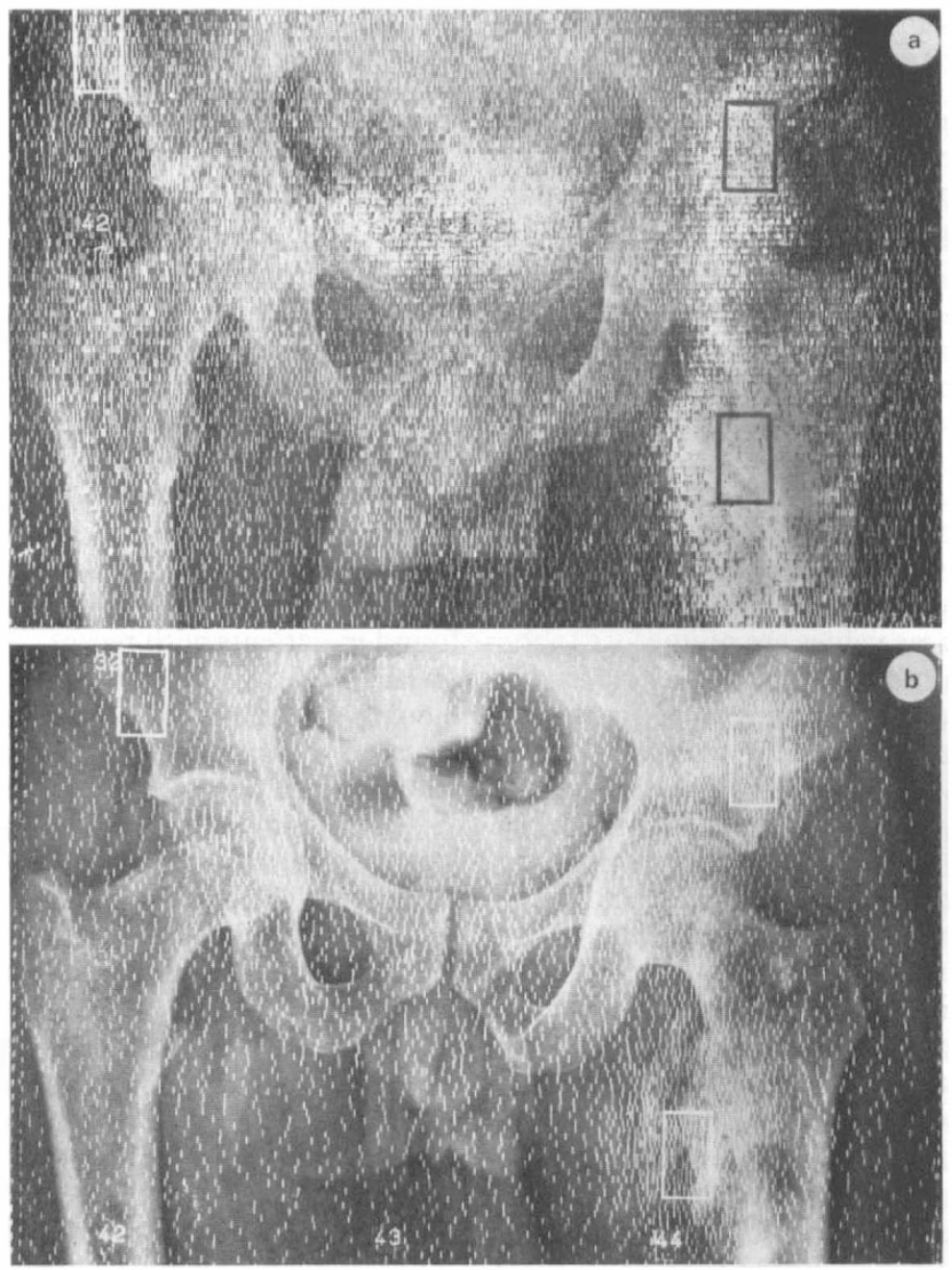

FIG. 7, A and B (Case 2)

A, ${ }^{87 \mathrm{~m}} \mathrm{Sr}$ scintigraphy one month after clinical onset of POA shows increased uptake by the two ectopic bony masses, above the femoral neck and in the intertrochanteric region. The squares indicate the areas which were counted in order to calculate the uptake ratio of the ectopic bone formation to the anterior superior iliac spine. This ratio is 5.5 for the trochanteric mass and 4.6 for the mass above the femoral neck (see also fig. 7, c). B, ${ }^{87 \mathrm{~m}} \mathrm{Sr}$ scintigraphy $4 \frac{1}{2}$ months af ter clinical onset of POA. The uptake ratio has dropped to 2.9 for the trochanteric mass, but remains high, $4 \cdot 2$ for the mass above the femoral neck (see also fig. $7, c$ ). 


\section{CONCLUSIONS}

(a) The development of POA may be associated with elevated urine Hyp.

(b) Normalisation of urine Hyp levels does not mean that the POA is stabilised. stabilised.

(c) The persistance of elevated urine Hyp does not mean that POA has not

5. Skin Temperature Measurements. In the acute phase of POA, adjacent skin temperature is frequently found to be elevated. This temperature elevation may be highly transitory, as may be the other stigmata of inflammation. The classical tetrad of inflammation seems to be of value only in diagnosing the clinical

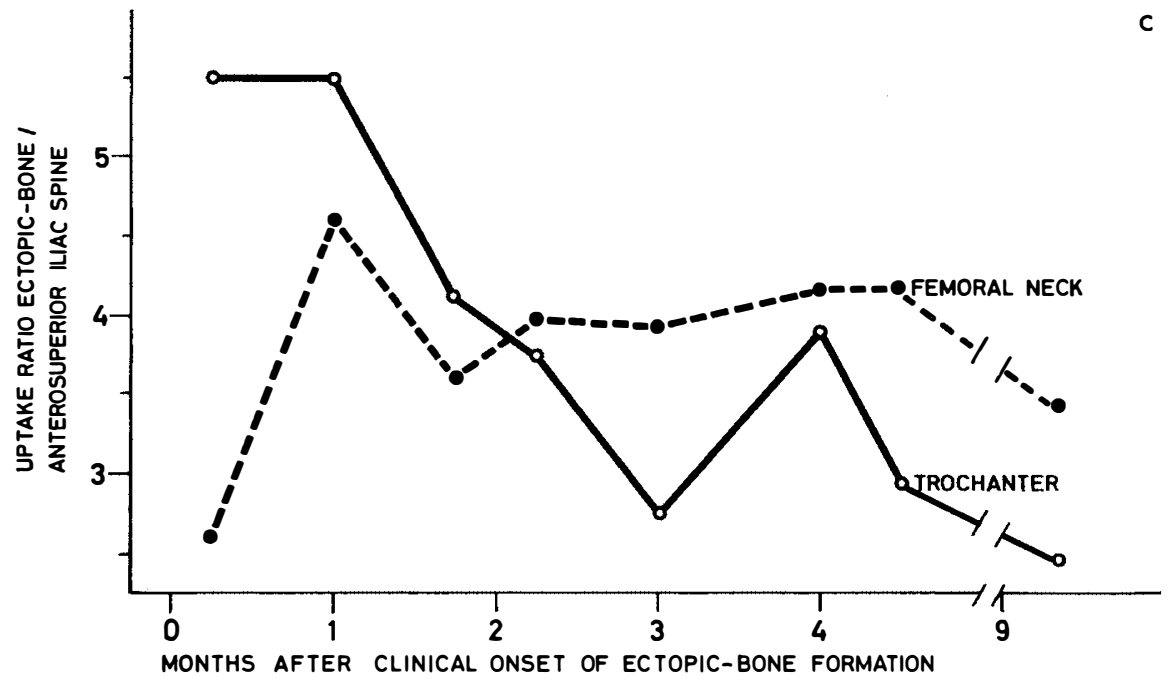

Fig. 7, C

Uptake ratios of eight consecutive ${ }^{87 \mathrm{~m}} \mathrm{Sr}$ scintigraphies in the same patient.

onset of POA. Normalisation of the skin temperature over the POA (the controlateral side serving as a control in unilateral lesions) does not permit any conclusion as to the degree of maturity of the POA process.

6. Bone Scanning. It would seem that bone scans would provide valuable information, not only about the activity, but also the degree of maturity of POA lesions. We began with ${ }^{85} \mathrm{Sr}$, but the long half-life of this isotope, 65 days, and the relatively large radiation dose to the patient, limited the number of serial scans able to be performed. The authors prefer to use ${ }^{87 \mathrm{mSr}}$ now, whose half-life of 2,8 hours allows us to perform bone scans practically as often as we like, making it possible to follow the evolution of the POA in terms of radioisotopic uptake.


injection of $100 \mu \mathrm{Ci}$ of ${ }^{85} \mathrm{Sr}$, we scanned the pelvis and knees if involved by POA. The scanning was performed by a Mecaserto $\mathrm{MO}_{4}$ (Mecaserto, Paris) scintigrapher. A network of lead coordinates incorporated in the table allows superposition of the simultaneously made X-ray and scan (fig. $7, a, b$ ). The number of counts found 
over a surface of $17 \times 30 \mathrm{~mm}$. of the maximum POA activity is divided by the number of counts found on an identical area of iliac crest, giving an uptake ratio independent of the dose injected (fig. $7, a, b$ ). Calculation of this ratio allows direct comparison of uptake between two or more separate scans (fig. $7, c$ ). To our knowledge, this is the first time this calculation has been employed (Muheim et al., in press).

\section{A. Chronic POA}

\section{RESULTS}

I. Unoperated Cases (cases not cited in Table I). Two patients with chronic POA had a single ${ }^{85} \mathrm{Sr}$ scan. The first had bilateral hip POA of 4 years' duration; the uptake was almost normal. The second patient with bilateral knee POA of $2 \frac{1}{2}$ years' duration, had an increased uptake. A third patient with bilateral knee POA of 3 years' duration, showed slightly increased uptake bilaterally which remained unchanged at a second scan, one month later.

2. Operated Cases. One patient (case Io) had both hips operated without recurrence ( 12 months post-operatively to date), after a series of four ${ }^{85} \mathrm{Sr}$ scans spread over a period of 13 months. The scans in this case showed constantly diminishing uptake: in 13 months the uptake ratio went from $\mathrm{I} \cdot 9 \mathrm{I}$ to $\mathrm{I} \cdot 54$ on the right and from 2.48 to $\mathrm{I} \cdot 7 \mathrm{I}$ on the left.

Another patient (case 3) with bilateral hip POA of 2 years' duration, was operated on the right side, although his ${ }^{85} \mathrm{Sr}$ uptake ratio increased from $4 \cdot 72$ to 5.30 in an interval of $2 \frac{1}{2}$ months. This patient had a severe recurrence postoperatively. He was subsequently operated on the left side, after three scans over a period of $4 \frac{1}{2}$ months, during which time his uptake ratio went from 8.68 to 14.9 , declining finally to $12 \cdot 25$. There was a slight, localised post-operative recurrence.

\section{B. Acute POA}

Unoperated Cases. In four of six patient who had from two to eight ${ }^{87 \mathrm{~m} S \mathrm{~S}-}$ scintigraphies, it was found that uptake diminished as the POA aged (observation over a period of 4 to 9 months) to become normal again in two of the patients, af ter 4 and $6 \frac{1}{2}$ months respectively. In a fifth patient (case 17), the uptake remained elevated during Io months without variation. In a sixth patient (case 2) followed with scans from the clinical onset of POA on the left hip, one bone focus at the level of the lesser trochanter showed a steady diminution of the uptake ratio over a period of observation of 5 months. A second focus above the femoral neck showed a steadily increasing uptake ratio, which decreased in the ninth month (fig. $7, c$ ). At the same time, however, two other POA of recent onset which were developing at both femoral shafts showed an increased uptake (fig. $6 a, b$; Table III).

\section{DISCUSSION}

The results of various scans show that even POA of several months' or years' duration may continue to demonstrate pathological $\mathrm{Sr}$ uptake, a conclusion supported by Limbers and Donnan (I97I). Some POA, just as old, may have a normal Sr uptake. The uptake in some POA may increase with time, whereas in others the uptake may remain elevated. Finally, two POA of simultaneous onset in different locations, do not necessarily evolve identically: of the two, one may show a steady decrease and the other a progressive increase in Sr uptake (fig. 7, c). 
Four other patients included in this series (cases $8, \mathrm{I}_{2}, \mathrm{I} 3, \mathrm{I} 5$ ) representing five POA, two of which in the same patient (case I 5), had only a single pre-operative bone scan. In each case the uptake at the POA site was pathologic compared with the activity of adjacent bony structures. There was no recurrence during a postoperative follow-up of between 2 and $2 \frac{1}{2}$ years.

At this point in our understanding of POA, it is difficult to state at what absolute value of uptake it may be concluded that a lesion has become stable. It does appear certain that progressive increase in $\mathrm{Sr}$ uptake ratios signifies an active process; a contraindication to surgery. No valid conclusions about the state of activity of a POA lesion may be drawn from a single, isolated scan. Depending on the evolution of the lesion, the uptake ratio may be found to be high or low. An almost normal uptake value may suggest stabilisation of the lesion; however, a single abnormal uptake value may not be interpreted one way or another.

A single, abnormal value might reflect a growing POA, or just as easily, a maturing, stabilising POA. For this reason, we attach no significance to a unique scan, even when the uptake in the area of the POA is abnormal when compared with normal adjacent bone. The fact that none of the patients with a unique scan showing pathologic uptake suffered from post-operative recurrence seems to bear out our conviction.

\section{CONCLUSIONS}

I. A single isolated bone scan is not sufficient to judge the maturity of a POA lesion.

2. As all POA do not behave in the same fashion, only serial scans may yield reliable information about the evolution of ectopic bone process.

3. A decrease in uptake over a period of time seems to suggest a slowing of the disease process.

4. An increase in uptake over a period of time signifies active disease, a contraindication to surgery.

5. When uptake ratios, determined from serial bone scans, show a progressive decrease, one may conclude that the lesion has reached maturity and that the risk of post-operative recurrence is minimal.

\section{SURGICAL ASPECTS OF POA}

Material and Methods. During the period from April I 968 to October I97I, we resected II POA in seven patients. In six hips and one elbow, the POA mass formed a bridge over the joint, resulting in complete ankylosis. In two hips and one elbow, the POA allowed a play of to to 20 degrees of flexion-extension. In one hip there remained 55 degrees of flexion. Seven bone biopsies were performed in six patients, five of whom presented acute POA, for which corrective surgery was not contemplated. The hip was generally approached by the Smith-Petersen incision, since most of the POA developed anterior to the joint. The two elbows were exposed by a medial approach with anterior transposition of the ulnar nerve. The POA was exposed and its relation with the adjacent structures was described as precisely as possible. The bony bridge was then resected in successive sections, beginning with the resection of a central triangle. Particular care was taken in exposing the deep aspect of the POA since the articular capsule was not always well 
defined and the joint surface itself could have been easily injured. Resection was not complete, but extended to the anterior inferior iliac spine superiorly and to a short distance from the femoral shaft, inferiorly. Biopsies were made at different sites with the pathologist present in order to achieve the best possible topographical description.

The borders of resection were treated as follows: sponging the surface with sponges soaked in 4 per cent. formol, electro-coagulation of the bleeding bony surfaces and finally, covering the open surface with a layer of bone wax (Michaelis, 1964). The operative wound was closed with negative pressure drains which were left in place 2-4 days. Once the drains were removed, passive mobilisation was begun with care, because of the fragility of the atrophic bony parts, stress stimulation being absent on account of the POA, as well as to reduce the risk of haemorrhage.

\section{RESULTS}

With each resection, a satisfactory mobilisation of relatively impotent or completely fused joints, prior to operation was obtained. In five of seven patients whose X-rays showed no evidence of recurrence, the mobility obtained at operation was generally conserved, improving with time and exercise.

There were recurrences in two patients (cases 3 and 4). In the first (case 3 ), the POA recurred bilaterally at the hips on the 14 th post-operative day on one side and on the 36 th post-operative day on the other side, a large recurrence on the right and a slight recurrence on the left. In the second patient (case 4), the POA recurred bilaterally at the elbow. However, on the left, the recurrence must be interpreted in light of the fact that supracondylar stress fracture occurred, in spite of very careful mobilisation. It became necessary to abandon physiotherapy; the fracture healed with a severe recurrence of the POA. Five days before the discovery of the fracture, the elbow could be extended $-25^{\circ}$ and flexed $120^{\circ}$.

At the right elbow, the POA recurred on the 3 Ist post-operative day. There was no loss of articular mobility. The joint remained mobile in spite of a radiological image practically identical to that found prior to the resection when the elbow had no mobility at all.

The first patient was operated upon at a time when the authors' experience in interpreting bone scans was not yet sufficient. The second patient was operated early in this study and thus did not benefit from all the prognostic parameters later employed.

Many authors have emphasised the ineffectiveness of surgical treatment of POA: frequency of recurrence (Bétoulières, I962; Faubel, 196I; Recordier et al., I96I), systematic post-operative aggravation (Bénassy et al., I963), and recurrences and infections (Armstrong-Ressy et al., 1959; Damanski, I96I; Michaelis, 1964). Grueter and Busack (1962) suggested amputation of lower limbs in which several articulations were involved. Although we experienced four recurrences (including one debatable elbow recurrence) in two patients, out of a total of I I operations on seven patients, there were no other complications, in particular no post-operative infections. The patients who suffered POA recurrences, nevertheless, benefited from a significant improvement in articular freedom.

When a POA is easily accessible, depending on its site, the danger of aggravating the lesion by biopsy (Faubel, I96I), seems slight. There was no incidence of aggravation after any of the biopsies in this study. 


\section{PATHOLOGICAL STUDY ${ }^{6}$}

This study centres on POA affecting the hip region; complementary data were obtained from POA at other sites.

\section{POA of the Hip Region}

Nine specimens of long standing (chronic) POA were examined in six patients (cases 3, 8, IO, I2, I3, I5) and four specimens of POA of recent onset (acute) in four patients (cases I, 2, I6, I7).

A. Long Standing POA. Tissue was obtained from six patients, operated from 8 to 47 months after onset of the neurological lesion, i.e. from 7 to 46 months after clinical onset of POA.

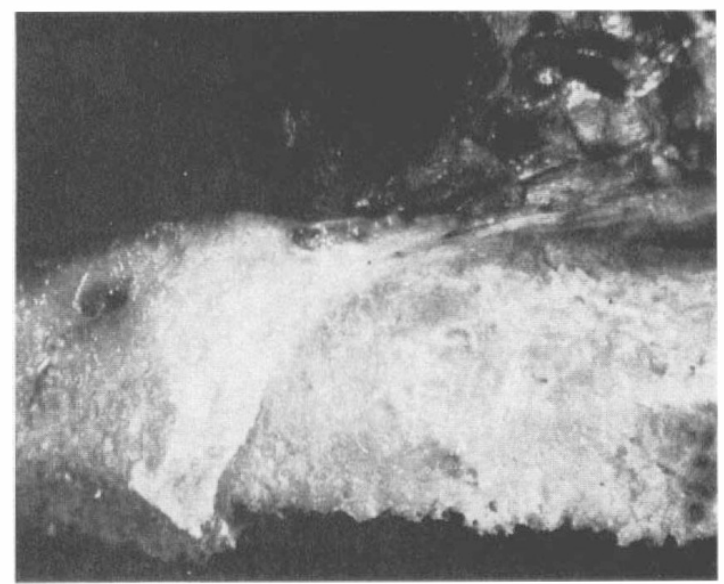

FIG. 8

Longitudinal section through a long standing POA (case I0), which developed around the distal tendon of the rectus femoris. The tendon tunnels diagonally through the ectopic bone; peripheral tendon bundles insert into the POA. Some proximal muscle fibres are visible on the right. $\times$ I.2. Biopsy TI3137/7I.

(a) Topography. In all cases, muscular masses adjacent to the POA were well defined and without atrophy. In five out of nine operated POA, adjacent tendons and muscles, especially the rectus femoris and the iliopsoas, lay in grooves over the ectopic bony mass or, occasionally, tunnelled through the mass (fig. 8). Tendon and muscle, as well as aponeurosis or joint capsule were sometimes firmly attached to the ectopic bone (cases 3, 10; fig. 9; fig. 8). Histologic study showed that atrophic muscular fibres were occasionally incorporated within the bony mass (fig. IO).

In two cases, at operation, a clearly pre-existent vascular formation was seen to penetrate the POA; this observation was confirmed histologically (cases Io and I5).

${ }^{6}$ This study was made by R. Lagier and G. Gabbiani with the support, in part, of the Commission Fédérale des Maladies Rhumatismales (Berne), and of the Fonds National Suisse de la Recherche Scientifique (grant No 3.356.70). 
The mass of ectopic bone was also found to have close relationships with the adjacent iliac bone and the femur. In two specimens (cases 8 and I5), where the femoral attachment of the inferior pole of the POA was studied, the femoral cortex was intact; the POA bone was attached directly to the surface of the cortex. In two


FIG. 9

Pre-existing tendon bundles insert into the cortex of a chronic POA of the hip (case 3$)$. The same region is shown photographed, $(a)$ with transmitted light, and, $(b)$ with polarised light. Haematoxylin \& eosin. $\times$ I3. Biopsy TII754/7r.

other specimens (case I0) where the implantation of the POA on the iliac bone was studied (fig. I I), POA bone merging with the iliac bone was found, with disruption of the normal cortex. The two osseous structures retained their typical characteristics, in spite of the loss of defined limits between them. The iliac bone showed regular lamellar architecture with haemopoiesis, while the POA showed more irregular structure, as described below, with practically no haemopoiesis (fig. I2; fig. I I).

The pathology observed was found to be strictly extra-articular. In case I3, 
open inspection of the joint space demonstrated integrity, suggested by radiologic evidence, of the articulation itself, and, of the cartilaginous surfaces, confirming the concept established since the original observations of Déjerine et al. (I9I9). The articular capsule appeared as a thin layer of connective tissue adhering to the adjacent POA; the synovium was not distinguishable.

(b) Structure. The POA mass consists of a cortex, about I mm. thick, and a tightly latticed spongiosa; the cortico-spongiosal limits are less well defined than in normal bone. The bone of POA is harder than normal bone. POA is lamellar, with occasional Haversian systems, showing structural features which distinguish it from normal bone. These features are found in all non-tumoural new bone formation (e.g. fracture callus).



Fig. IO

Transverse section of a long standing POA showing bundles of muscle fibres among the trabeculae (case Io). These bundles are surrounded by an oedematous connective tissue within an adipose bone marrow. Only some of these muscle fibres are stained in red. A bony trabecula is visible. Goldner trichrome. $\times 30$. Biopsy TI3137/7I.

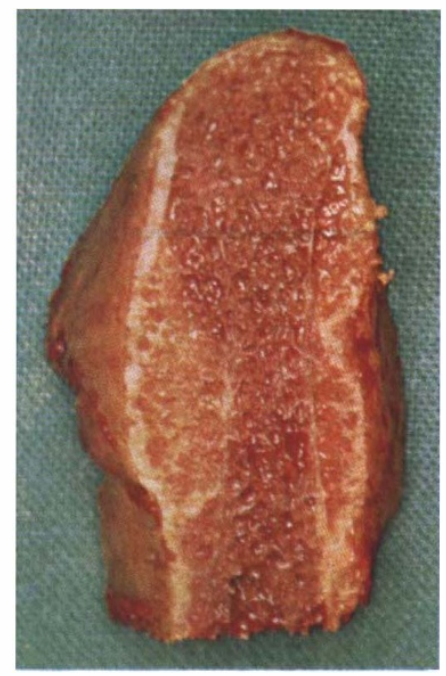

FIG. II

Gross comparison of ectopic and pre-existing bone (case IO). The left iliac crest, containing haemopoietic bone marrow, is surrounded by newly formed bone, containing adipose bone marrow. $\times \mathbf{I} \cdot 2$. Biopsy TI3I37/7I.

The central part of the trabeculae is occasionally replaced by the remains of woven bone, particularly easy to identify when marked by tetracyline administration during its formation period. The rarity of osteoblasts and osteoclasts indicate that remodelling is not very active; although more so than in normal bone. This picture correlates with data, obtained from isotopic scanning, showing that radionuclide uptake usually diminishes as the POA ages.

The bone marrow is essentially adipose, occasionally with a fine fibrillar appearance, perhaps related to a somewhat greater than normal endosteal activity. Haemopoiesis is absent, or very discrete (Alex, I959; Bénassy et al., I963).

We were impressed by the occasional presence of microfractures, of apparently transverse orientation, obviously superimposed on already well organised bone. I I $/ \mathrm{I}-\mathrm{F}$ 
Sometimes, the image was one compatible with fibrocartilagineous pseudoarthrosis. It is possible that occasional increases in radionuclide uptake, during the evolution of the POA, might be explained by the presence of these microfractures.

In places, the POA bone is flanked by areas of oedematous fibroblastic connective tissue, without inflammatory infiltration or osseous metaplasia. Such tissue is noted lining grooves along the surface of the POA, as well as in association with atrophic muscular fibres, embedded in the bony mass. The presence of oedematous and gelatinous tissue in the cavities of POA has been already described by Déjerine et al. (1919). Electron microscopic examination reveals that this

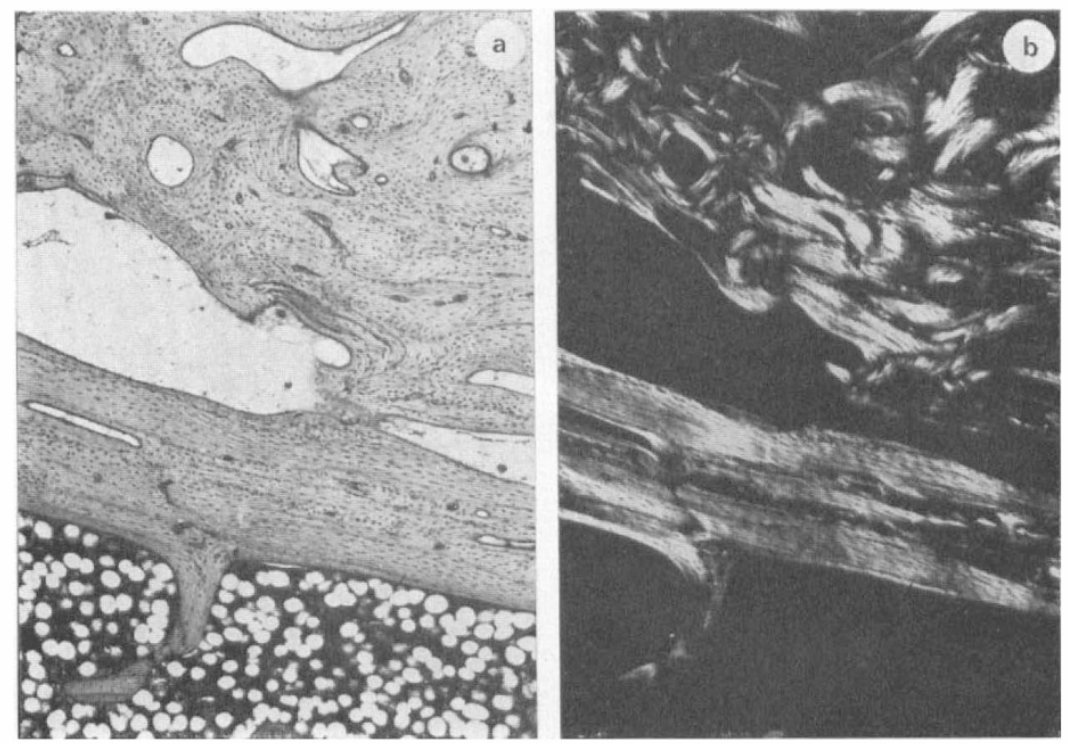

FIG. I2

Microscopic comparison of ectopic and pre-existing bone (detail of fig. I I). The same field is seen, $(a)$ with transmitted light and, $(b)$ polarised light. Above: long standing POA containing adipose marrow, with trabeculae undergoing some remodelling. Below: normal bone of the iliac crest: the cortical and spongiosal trabeculae are regular and the marrow is haemopoietic. Haematoxylin \& eosin. $\quad \times 33$.

connective tissue is composed of fibroblasts, ground substance and three types of fibres:

I. well formed collagen fibres, in small quantities;

2. immature collagen, in larger quantities;

3. microfibrils without periodicity, that, because of their smaller diameter, can be distinguished from the immature collagen fibres.

This composition is typical of young connective tissue, and it is remarkable to find such characteristics persisting in an apparently stable tissue, adjacent to long standing POA.

B. Recent POA. Tissue was obtained from three specimens of clinically very early POA: I. 34 days after spinal cord injury and 5 days after the first 
radiologic signs (case I6); 2.64 days after spinal cord trauma and 7 days after the first radiologic signs (case 2); 3. 506 days after cord injury and I3 days after the first radiologic signs (case I). In addition, tissue was obtained from a fourth case 4 months after the onset of hemiplegia; 8 weeks after the POA was diagnosed (case 17 ).

(a) Topography. In the four cases just mentioned, the POA developed within a muscle: the rectus femoris (case 2), the vastus lateralis (case I), the iliacus (case 17 ) and the vastus intermedius (case I6).

Generally, the muscle was observed to be compressed by the underlying POA. It was concluded that the POA arose at the periphery of the muscle. At operation, the POA masses were found to be delimited laterally, and, although more difficult to expose, were likewise delimited proximally and distally. The precise relationship of the POA to adjacent bone structures could not be established in each case, because the operative exposure was small.

It is interesting to note that in case $\mathrm{I}$, and especially in case 2 , oedematous connective tissue was found between the POA itself and the remaining muscle. In case 17 which was a clinically more advanced lesion, the surgeon observed a conspicuous plane of cleavage between the POA and adjacent muscle.

In general, the POA was highly vascular, particularly at its periphery; the biopsy samples were very haemorrhagic.

(b) Structure. At operation, the masses were very firm, but not as hard as normal bone, or long standing POA and were made up of oedematous, fibroblastic, osteogenic, connective tissue, without inflammatory infiltration, with the exception of some lymphocytes. Microscopically, many small vessels were observed; the newly formed bone consisted of woven trabeculae undergoing osteoclastic erosion (fig. I3). In places, appositional bone was found beginning the formation of a lamellar structure. Electron microscopy showed the usual characteristics of fibrillar ossification in progress (fig. I4).

Such active osteogenesis explains the uptake of tetracycline, which gives the new bone a grossly visible golden yellow fluorescence, distinguishing the POA from its adjacent structures. This osteogenic activity is associated with an elevated serum alkaline phosphatase. In places, bone formation was accompanied by chondrogenesis as previously described (Bétoulières, I962; Miller \& O’Neill, I949); an association common in reparative processes. In case 2 , the zones of cartilage were sometimes oriented in bands, suggesting the influence of mechanical forces.

Occasionally, especially at the periphery of the specimens, we found numerous atrophic muscular fibres (Hardy \& Dickson, 1963; fig. 13), which were sometimes dissociated, undergoing lysis (cases I, 2, I7; fig. I3).

Electron microscopy showed that these muscle fibres have lost their striation and sarcotubular systems. These fibres contained multiple dense bodies, probably ferritin. Thick collagen and elastic bundles, apparently derived from pre-existing tendon or aponeurosis, were also present (fig. I5).

These observations demonstrate conclusively the inclusion of muscle and aponeurotic tissue within the POA mass, already suspected on the basis of topographic and histologic examination of old POA.

At the periphery of the osteogenic tissue there was oedematous, but unossified, connective tissue. This tissue was shown, by electron microscopy, to be morphologically similar to the connective tissue, previously described, adjacent to old POA (fig. I5). Occasionally (electron microscopy confirmed the light microscopic 

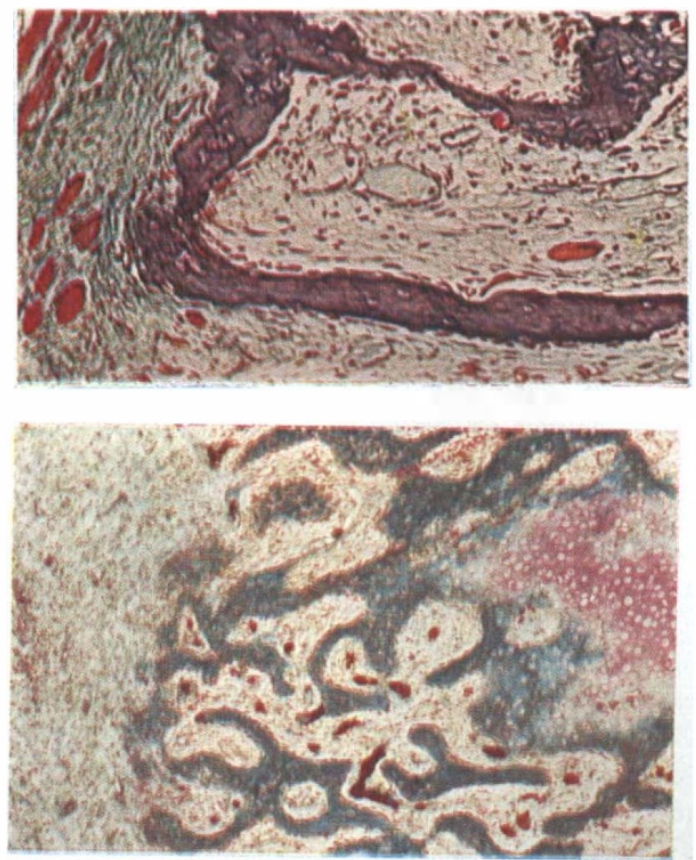

FIG. I3

Recent POA (case 2), with adjacent muscle. (a) Trabeculae of woven bone, occasionally undergoing osteoclastic erosion. On the left, muscle fibres surrounded by fibrous connective tissue. Among the trabeculae, the adipose bone marrow shows non-specific inflammation and capillary stasis. On the right, a remnant of a muscle fibre incorporated within the newly formed bone. (b) Younger bony trabeculae than in (a), among which are seen capillaries filled with red blood cells. Adjacent, an area of cartilage. On the left, finely fibrillar, oedematous connective tissue. Goldner,trichrome. $(a): \times 95 .(b): \times 30$. Biopsy T2087/72.



FIG. I4

Electron microscopic detail of an osseous trabecula in a recent POA (case I). A typical osteocyte (left) is separated by a space (containing only a finely fibrillar material) from a dense mass of apatite crystals (right) deposited along collagen fibres. $\times 25000$. Biopsy T8688/7I. 
studies), unorganised calcareous deposits were found within this oedematous connective tissue (fig. I5), especially in the vicinity of muscular fibres undergoing necrosis. Electron diffraction studies showed that these calcareous deposits contain randomly oriented apatite crystals.

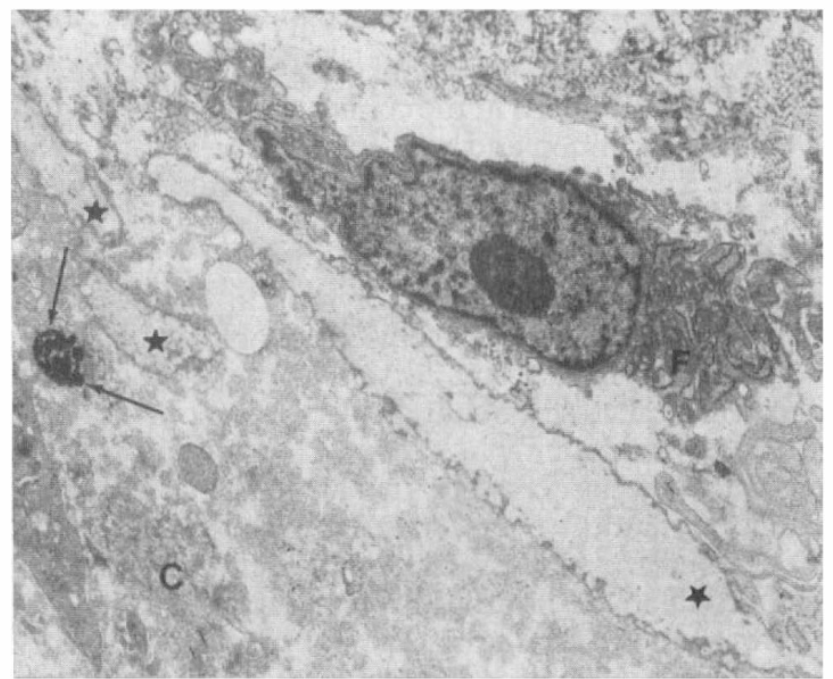

FIG. I5

Electron micrograph: oedematous connective tissue in a recent POA (case 2 ). Thick bundles of fibrillar material $(\star)$, probably pre-existing, are found close to a fibroblast $(\mathrm{F})$. The remaining extracellular space is composed of collagen fibres (C) and microfibrils. Dystrophic calcification (arrows) is also present. $\times 9500$. Biopsy T2087/72.

\section{POA in Other Sites}

Three specimens of long standing POA at other sites were collected: the two elbows in case 4, and the knee in case I4. These patients were operated between 9 and 15 months after injury. The topographical relationships with the adjacent muscle were not clearly established at operation; however, their morphology was analogous to that of the long standing hip POA. In one elbow with intact cartilaginous surfaces, the synovium was oedematous, but showed no hyperplastic or inflammatory changes.

In a single specimen from a recent POA of the knee (case 6) the topographical observations at operation were followed by macroscopic studies, demonstrating that the POA originated in the tendino-aponeurotic tissue of the pes anserinus; histologic study confirmed the absence of any involvement of muscular tissue. The histologic features of this case were similar to those of the cases of recent hip POA, with presence of osteo- and chondrogenic connective tissue and multiple dystrophic calcifications. It seems that the process here is analogous to that of other recent POA, the difference being that the starting point was tendino-aponeurotic tissue, rather than muscle.

In each of these cases, the pre-existing skeletal structures showed discrete signs of remodelling comparable with those observed in Sudeck's atrophy. 


\section{CONCLUSIONS}

I. POA is the result of metaplasic osteogenesis of apparently rapid onset, associated with some chondrogenesis, forming cortico-spongiosal bone of lamellar structure. Such bone shows features which differentiate it from adjacent normal bone.

2. POA may develop without any connection with muscular tissue, notably in aponeurotic tissue, and possibly also in the connective tissue separating muscle mass. POA may involve fibres of tendon and may surround vessels; however, most of ten, the POA develops in the muscular periphery, deriving from the interfascicular connective tissue, giving rise to a picture seen in some types of myositis ossificans, particularly of the post-traumatic type. This observation, from the study of recent cases, is borne out by the finding of muscle fibres incorporated in long standing POA, a finding which seems to discount observations in earlier cases of long standing POA, where the surgeon, as well as the pathologist, described completely normal muscular anatomy about the ectopic bone mass (Rouquès et al., 1954; Bétoulières, 1962; Freehafer et al., 1966). During the evolution of the POA, a plane of cleavage may develop between the evolving POA, including the affected peripheral muscle fibres, and the main muscular mass, as seen most clearly in cases I, 2, and 17 . The site of the lesion varies in different subjects: in addition to the more common periarticular localisation, heterotopic ossification may be observed at some distance from the skeleton, as already observed by Déjerine et al. (I9I9). Multiple foci of osteogenesis have also been reported (Bénassy et al., I963; Hardy \& Dickson, I963).

3. We were impressed by the oedematous and immature aspect of the connective tissue involved in the cases of recent POA; such tissue may also be seen associated with long standing POA. It seems that, at first, there forms a swollen connective tissue, which may or may not be located between peripheral muscular fibres. For a time, the duration of which remains to be defined, parts of this oedematous connective tissue, especially within the muscle, may undergo ossification. The unossified connective tissue persists, retaining its immature characteristics, while the osteogenic connective tissue matures, becoming distinct from the main muscle mass.

4. We noted the presence of occasional microfractures which may modify secondarily the morphological aspect of the POA. These microfractures may be related to the patient's spasticity, or perhaps, to passive mobilisation.

\section{ULTRASTRUCTURE AND DISTRIBUTION OF MINERAL SALTS IN POA TISSUE}

The mean degree of mineralisation of POA, measured by micro-radiography and expressed as grammes mineral per cubic centimetre of calcified substance (Jowsey, 1964), varies with the age of the lesion. During the first 18 months, the active period of formation and remodelling, the average mineralisation ranges from 0.90 to $\mathrm{I} .00 \mathrm{~g} / \mathrm{cm}^{3}$ Later, with maturation of the lesion, the average mineralisation increases to $1 \cdot 15 \mathrm{~g} / \mathrm{cm}^{3}$ after 24 months, and up to $1 \cdot 19 \mathrm{~g} / \mathrm{cm} .{ }^{3}$ at 30 months.

Histograms showing overall distribution of mineral content in the POA bone tissue indicate, with age, a progressive decrease in volume occupied by less mineral- 
ised substance and an increase in volume occupied by heavily mineralised substance.

Comparison of these values with those obtained from normal controls (tibial malleolus) shows that the degree of mineralisation is much less in POA tissue than in normal bone during the first 18 months, in individuals of the same age. POA mineralisation after 30 months approaches that of normal young adult bone.

$\mathrm{X}$-ray diffraction studies show that amorphous calcium phosphate forms a major part of the mineral content of POA tissue. This non-crystalline component varies little during the first 12 months of the lesions' development, constituting about 58 per cent. of the mineral content. Later, this percentage slowly diminishes, falling to 40 per cent after 30 months, still greater, however, than in normal adult bone. This is an important consideration, since the amorphous and the crystalline components behave quite differently in mineral metabolism. The amorphous component is a metabolically active, metastable precursor of the crystalline component (Lopez et al., 1970).

The apatite crystals found in the crystalline component are of small dimensions. Their length may be calculated from the $\beta$ index, i.e., the line breadth, at halfmaximum intensity, in the X-ray diffraction pattern (Posner et al., 1963). The length of the crystal is inversely proportional to the (002) $\beta$ index. The size of the crystal is very small during the first 24 months of the lesion's evolution and there is very little variation during this period $(\beta=0.54)$. In 30 month-old lesions, the crystals are noticeably smaller $(\beta=0.49)$ than the crystals of normal adult bone $(\beta=0.365)$, meaning that the surface developed by the crystalline component of the mineral substance is much larger in POA, than in normal bone.

Finally, in POA tissue, the dimensions of the unit cell of the apatite lattice (characterising the crystalline component) are slightly larger than those of normal human bone (Baud \& Lee, I969).

This difference may be due to heteroionic substitutions which are presently under study.

\section{CONCLUSION}

The ultrastructure and distribution of mineral salts in POA tissue were studied from early deposition to maturity.

The sequence of transformations involved a progressive increase in degree of mineralisation, with a relative diminution of the amorphous phase and an enlargement of the crystal size. After 30 months, the pattern in POA tissue approaches that of normal young adult bone.

\section{CONCLUSIONS AND SUMMARY}

I. Twelve cases of chronic POA and five cases of acute POA from clinical and radiologic onset were studied in the light of the following parameters: X-rays; lower limb angiographies with venous and arterial blood gas analysis; serial determinations of urine hydroxyproline; urine calcium, serum calcium and phosphorus; creatinephosphokinase; alkaline phosphatase; bone scans; skin temperatures; bone biopsies in evolving POA; light and electron microscopic studies; analysis of amorphous and crystalline components and fluorescent study of ectopic bone marked with tetracycline. 
2. The most common localisation of heterotopic ossifications is periarticular; however, it may also be observed at some distance from the skeleton (cases I and I6).

3. Onset of POA is accompanied by angiographic modifications showing regression as the POA ages. However, one may not conclude from the persistance of angiographic modifications that the POA is not yet mature. Nor does normalisation of an initially pathological angiogram signify that the maturation of the ectopic bone formation is complete and the POA stabilised.

The angiographic modifications associated with POA are secondary to the POA and not the cause.

4. Arteriovenous blood gas determinations correspond in general to the angiographic modifications and are of no value in judging the degree of maturity of the ectopic bone.

5. The development of POA may be associated with elevated urine Hyp. Normalisation of Hyp levels does not mean that the POA has stabilised; persistance of elevated values does not mean that the POA has not stabilised. Urine Hyp determinations do not permit any conclusion as to the degree of maturity of the POA lesion.

6. Elevation of serum alkaline phosphatase is a sign of the presence of pathologic growing bone, a contra-indication to POA surgery. Normalisation of this enzyme value does not constitute adequate proof of the stabilisation of the osteogenic process.

7. Infrequent isolated determinations of the alkaline phosphatase and of urine Hyp are of practically no value in following the evolution of POA. As for angiographies and bone scans, the dynamic picture produced by serial determinations gives a better idea of the status of the lesion.

8. Elevation of serum CPK suggests a participation of striated muscular tissue in the developing POA mass.

9. Determinations of serum calcium and phosphorus have been of no value in the diagnosis of POA, nor in the evaluation of the maturity of the ectopic mass.

IO. In serial bone scans, a decrease in radionuclide uptake over a period of time seems to suggest a slowing of the disease process: an increase signifies active disease, a contraindication to surgery.

II. Multiple foci of osteogenesis of simultaneous onset do not necessarily evolve identically (case 2 ).

I2. Serial bone scans seem to be the most reliable parameter for deciding when a POA is mature and may be operated. Although not constituting absolute proof of stabilisation of the osteogenic process, serial determinations of serum alkaline phosphatase are next in order of reliability.

I3. POA may develop without any connection with muscular tissue but, most often, the POA develops in the muscular periphery, deriving from the interfascicular connective tissue, giving rise to a picture seen in some types of myositis ossificans, particularly the post-traumatic type. Histologic studies have shown that atrophic muscular fibres may occasionally be incorporated within the bony mass.

I4. Light and electron microscopic examinations of I2 long standing POA (nine hips, two elbows, one knee) and of five recent POA (four hips, one knee) have shown that POA are the result of metaplasic osteogenesis, associated with some chondrogenesis, forming lamellar cortico-spongiosal bone. Therefore, the term 'calcification' does not apply to POA and may be abandoned.

15. The study of the ultrastructure and distribution of mineral salts in POA 
tissue, from early deposition to maturity, has shown that the sequence of transformation involves a progressive increase in the degree of mineralisation with a relative decrease of the amorphous phase and an enlargement in crystal size. After 30 months, the pattern in POA tissue approaches that of normal young adult bone.

I6. Injury may certainly be a causative factor in the onset of POA, as shown by cases 2,4 , and 16 , but other factors must be considered as well. The role of physiotherapy must be mentioned as a possible aetiologic factor, especially in association with marked spasticity (Hossack \& King, 1967). Microscopic interstitial haemorrhages may result from too brisk a mobilisation.

I7. If POA do occur more frequently in spastic patients, they may also take place in the absence of any spasticity, as shown by cases 1,6 , and 10 .

I8. Contrary to the views of Silver (1969), Stryker frames or turning beds, anticoagulant therapy and pressure sores do not appear to play an important role in the onset of POA. Cases IO and I2 were not associated with any of these factors at any time during their treatment.

19. Eleven POA were resected in seven patients (nine hips, two elbows). There were recurrences in two patients attributed to lack of experience at the time these patients were operated. With the exception of one elbow with a recurrence, all other operated joints enjoyed a significant improvement in articular freedom.

20. This study has produced valuable parameters for the determination of POA maturation allowing for the correct timing of operation with minimal risk of recurrence.

The question of the pathogenesis of POA has been answered only in part, and further study is needed, possibly with the help of bio- and histochemical techniques.

\section{CoNCLUSIONS ET RÉSUMÉ}

I. Ce travail a porté sur l'étude clinique de 12 cas chroniques et de 5 cas aigus de POA suivis, dès leur apparition, au moyen des paramètres suivants: radiographies, angiographies des membres inférieurs avec dosages des gaz dans les sangs veineux et artériel, dosages répétés de l'hydroxyprolinurie, de la calciurie, de la calcémie, de la phosphorémie, de la CPK, de la phosphatase alcaline, scintigraphies osseuses, mesures de la température cutanée, biopsies de POA au stade aigu, études histologiques au microscope optique et électronique, analyses du minéral amorphe et cristallin, examen, en lumière de fluorescence, de l'os marqué à la tétracycline.

2. Si les POA sont en général péri-articulaires, on peut également les trouver à quelque distance du squelette (cas I et I6).

3. La genèse d'une POA s'accompagne de modifications angiographiques qui tendent à régresser au fur et à mesure que la POA vieillit. La persistance de ces modifications ne permet cependant pas plus de conclure à l'immaturité de la POA que la normalisation d'une angiographie initialement pathologique n'autorise à considérer la POA comme mûre et stabilisée. Les modifications angiographiques observées dans les POA ne sont pas causées par l'ossification ectopique mais lui sont secondaires.

4. Les résultats du dosage des gaz sanguins correspondent en général aux modifications angiographiques; ils ne sont cependant d'aucune valeur pour juger du degré de maturité de l'os néoformé.

5. L'installation d'une POA peut s'accompagner d'une élévation de l'hydroxyprolinurie. Le retour à la norme des valeurs de l'Hyp ne signifie pas pour autant la stabilisation de la POA, pas plus que la persistance de valeurs élevées n'implique une instabilité de l'os néoformé. Les dosages de l'Hyp ne permettent pas de tirer de conclusion sur le degré de maturité de la POA.

6. L'élévation des valeurs de la phosphatase alcaline signe la présence d'un processus osseux pathologique en évolution, contre-indiquant toute chirurgie de la POA. Le retour à

$$
\text { I I } / \text { I-G }
$$


la norme de ces valeurs n'est cependant pas une preuve suffisante qui permette de conclure à la stabilisation du processus ostéogénique.

7. Les dosages isolés et irréguliers de la phosphatase alcaline et de l'Hyp sont pratiquement sans valeur pour suivre l'évolutivité d'une POA. De même que pour l'angiographie et la scintigraphie osseuse, seule la répétition des examens, à intervalles réguliers, donne une image dynamique qui permet d'apprécier l'état de la lésion.

8. Une élévation des valeurs de la CPK laisse penser que des fibres musculaires striées se trouvent impliquées dans la POA en voie de formation.

9. Les dosages de la calcémie et de la phosphorémie ne sont d'aucune utilité ni dans le diagnostic des POA ni dans l'appréciation du degré de maturité osseuse de ces néoformations.

Io. Une diminution de la captation isotopique, au cours de plusieurs scintigraphies osseuses étagées dans le temps, permet de conclure à un ralentissement d'activité du processus ostéogénique, alors qu'une augmentation signe, au contraire, un processus en pleine activité, contre-indiquant toute chirurgie.

II. Même si plusieurs foyers d'ostéogénèse se manifestent au même moment, ils n'évoluent pas forcément d'une manière similaire.

12. Répétée à intervalles réguliers, la scintigraphie osseuse semble être le paramètre le plus fiable pour déterminer si la POA est mûre et stabilisée et peut être opérée. Bien que les résultats des dosages de la phosphatase alcaline ne permettent pas de décider si une POA est mûre et stabilisée, dans l'ordre de la fiabilité, le dosage de cet enzyme occupe la deuxième place après la scintigraphie osseuse.

13. Une POA peut se dévolopper en dehors de tout contexte musculaire, bien que, le plus souvent, elle intéresse la périphérie du muscle, partant du tissu conjonctif interfasciculaire; elle présente alors une image similaire à celle que l'on peut voir dans certains types de myosite ossifiante, post-traumatique en particulier. Les examens histologiques ont clairement démontré que des fibres musculaires atrophiques pouvaient se trouver englobées dans la masse osseuse ectopique.

I4. L'examen, au microscope optique et électronique, de I2 POA au stade chronique ( 9 hanches, 2 coudes, I genou) et de 5 POA au stade aigu (4 hanches, I genou) a révélé que les POA sont l'aboutissement d'une métaplasie ostéogénique, associée à un certain degré de chondrogénèse avec, pour résultat final, formation d'un os lamellaire cortico-spongieux. Aussi, le terme de "calcification" ne s'applique-t-il pas à la dénomination des POA et devraitil être abandonné.

15. L'étude de l'ultrastructure et de la répartition des sels minéraux dans les POA, du stade initial de dépôt jusqu'à maturité osseuse, a montré, dans la séquence des transformations, une augmentation progressive du degré de minéralisation, une diminution relative de la phase amorphe et une augmentation de la taille des cristaux. Après 30 mois, l'ultrastructure et la distribution du minéral, dans les POA, s'approchent de celles de l'os normal chez le jeune adulte.

I6. Si un traumatisme peut jouer un rôle dans l'étiologie d'une POA, comme le montrent les cas 2, 4 et I6, d'autres facteurs entrent encore en considération. Il faut à ce propos, mentionner le role de la physiothérapie, en particulier dans les cas de spasticité marquée (Hossackand King, I967). Unemobilisation trop brusque desarticulations pourrait entraîner, dans le tissu interstitiel, des suff usions sanguines microscopiques.

17. Si les POA semblent prédominer dans les lésions spastiques, on peut également les trouver chez des patients sans aucune spasticité (cas I, 6 et IO).

I8. Il ne semble pas que le facteur étiologique prêté par Silver (1969) aux lits Stryker, aux lits tournants, au traitement anticoagulant et aux escarres joue un rôle important dans la genèse des POA; aucun de ces facteurs n'est entré en ligne de compte dans les cas Io et I2.

19. Onze POA chez sept patients ont été enlevées ( 9 hanches, 2 coudes). Par manque d'expérience dans l'interprétation des paramètres utilisés, deux patients présentèrent des récidives (cas 3 et 4 ).

Exception faite de l'opération d'un coude où la POA récidiva, toutes les autres interventions libératrices se traduisirent par une amélioration marquée du jeu articulaire.

20. Le but de ce travail a été de mettre en évidence les paramètres permettant de déterminer à quel moment une POA est mûre et peut-être opérée, en courant le moins de risques de récidive. Le problème de la pathogénie des POA n'a, par contre, été que partiellement résolu; d'autres travaux sont encore nécessaires, peut-être avec l'aide de la biochimie et de l'histochimie. 


\section{SCHLUSSFOLGERUNGEN UND ZUSAMMENFASSUNG}

I. Zwoelf Fälle chronischer und fünf Fälle akuter POA werden vom Beginn der klinischen und radiologischen Befunde an mit Hilfe der folgenden Parameter untersucht: Röntgenaufnahmen, Angiographien der unteren Gliedmassen mit arterieller und venöser Blutgasanalyse, serienweise Bestimmung von Harn-Hydroxyprolin, Alkalische Phosphatase, Harn-Kalzium, Serum Kalzium und anorganische Phosphate, CPK, Knochen-Szintigraphien, Hauttemperatur, Knochen-Probeexzisionen bei fortschreitender POA, licht- und elektronenmikroskopische Untersuchungen, Analysen der amorphen und kristallinen Phasen, Fluoreszenz-Untersuchungen mittels Tetrazyklin markierter ektopischer Knochen.

2. Das häufigste Vorkommen heterotoper Ossifikationen ist periartikulär, jedoch sind auch einige vom Skelett entfernten Verknöcherungen beobachtet worden (Fälle I \& I6).

3. Der Beginn der POA wird von angiographischen Veränderungen begleitet, die sich mit fortschreitender Entwicklung der POA zurückbilden. Angiographien, die sich im Verlauf der Zeit nicht verändern, sind kein unbedingt sicherer Beweis dafür, dass die POA noch nicht voll ausgebildet ist. Auch die Normalisierung eines zu Beginn pathologischen Angiogramms bedeutet keinesfalls, dass der ektopische Knochen das Reifestadium erreicht hat und das Wachstum abgeschlossen ist. Die angiographischen Veränderungen sind mit der POA verbunden und sind deren Folge, nicht deren Ursache.

4. Verschiebungen arterio-venöser Blutgasverhältnisse stehen im allgmeinen im direkten Verhältnis zu den angiographischen Veränderungen, sind jedoch ohne Bedeutung für die Bestimmung des Reifezustandes ektopischer Knochen.

5. Bei POA findet sich of erhöhter Harn-Hydroxyprolinspiegel. Auch hier ist die Normalisierung der Harn-HYPkonzentration kein Beweis dafür, dass sich die POA stabilisiert hat, und umgekehrt sind erhöhte Harn-HYPwerte kein sicheres Zeichen dafür, dass das Wachstum der POA nicht abgeschlossen ist. Harn-HYPbestimmungen erlauben deshalb keine Rückschlüsse auf den Grad der Reife einer POA.

6. Eine Erhöhung der Serum alkalischen Phosphatase spricht für einen ektopisch wachsenden Knochen und ist eine Gegenindikation zur Exzision der POA. Normalisierung dieses Enzym-Wertes ist jedoch ungenügender Beweis dafür, dass sich der osteogene Prozess stabilisiert hat.

7. Unregelmässige und sporadische Bestimmungen der Alkalischen Phosphatase und des Harn-HYPspiegels erlauben es nicht dem Verlauf einer POA zu folgen. Wie bei Angiographien und Knochen-Szintigraphien, sind serienweise Bestimmungen obengenannter Parameter notwendig, um sich ein dynamisches Bild von der Entwicklung einer POA zu machen.

8. Eine Erhöhung der Serum-CPK spricht dafür, dass quergestreifte Muskelfasern an der Entwicklung der POA beteiligt sind.

9. Bestimmungen des Serum Kalziums und anorganischen Phosphats sind gleichermassen wertlos bei der Diagnose einer POA, wie bei der Bewertung des Reifezustandes ektopischer Knochen.

I0. In serienmässigen Knochen-Szintigraphien bedeutet die Verminderung des Radionuklide-Gehaltes eine Verlangsamung des pathologischen Prozesses. Eine Erhöhung jedoch bedeutet ein aktives Stadium und zugleich ist eine Gegenindikation zum chirurgischen Eingriff.

II. Gleichzeitig an verschiedenen Orten einsetzende osteogene Prozesse entwickeln sich nicht unbedingt im gleichen Tempo.

12. Serienweise Knochen-Szintigraphien scheinen der zuverlässigste Masstab zur Bestimmung des Reifezustandes und der Indikation zur Exzision der POA zu sein. Zweitbester Kriterium zur Bestimmung des Reifezustandes einer POA ist die serienweise Bestimmung der Serum alkalischen Phosphatase.

13. Die POA kann sich weit entfernt vom Muskelgewebe entwickeln, aber in den meisten Fällen entsteht sie in dessen Peripherie und die erste Anlagerung besteht im interfaszikulären Bindegewebe und kann gelegentlich dem histologischen Bild gewisser Typen von Myositis ossificans ähneln, z.B. der posttraumatisch Form. Bei histologischen Untersuchungen findet man gelegentlich Muskelgewebe in der Knochenmasse eingeschlossen.

14. Licht- und elektronenmikroskopische Untersuchungen in 12 seit langem bestehenden (9 Hüftgelenken, 2 Ellbogengelenken, I Kniegelenk) und in 5 seit kurzem bestehenden POA haben gezeigt, dass die POA das Ergebnis einer metaplasischen Osteogenese ist 
verbunden mit Knorpelbildung, was dem histologischen Bild eines lamellären kortikospongiosen Knochen entspricht. Deshalb kann man bei der POA nicht von Verkalkungen reden.

I5. Untersuchungen der Ultrastruktur und der Verteilung der anorganischen Substanz im POA-gewebe von erster Anlagerung an bis zu deren Reifezustand haben gezeigt, dass der Mineralisierungsgrad progressiv ansteigt und die amorphe Phase sich relativ erniedrigt, während sich die Kristalle vergrössern. Nach 30 Monaten gleichen die Ultrastruktur und die Verteilung der anorganischen Substanz im POA-gewebe dem normalen Knochengewebe eines jungen Erwachsenen.

I6. Traumen können eine POA auslösen, wie es in den Fällen 2, 4, und I6 zutraf, jedoch müssen noch andere Faktoren berücksichtigt werden. Bewegungsübungen ebenso können zur POA beitragen, besonders wenn grosse Spastik besteht. Zu schroffe Bewegungen können mikroskupische interstitielle Blutungen verursachen.

17. Obwohl man die POA öfters bei spastischen Patienten antrifft, kann sie auch in Abwesenheit von Spastik vorkommen, wie bei den Fällen I, 6 und Io.

18. Entgegen den Ansichten von Silver (1969) spielen Stryker- und Dreh-Betten, Antikoagulanten-Therapie und Druckgeschwüre keine wesentliche Rolle beim Entstehen einer POA. Bei Fällen IO und I2 waren keine von diesen Faktoren vorhanden.

19. Bei sieben Fällen wurden I I POA operiert (9 Hüftgelenke, 2 Ellbogengelenke). Bei zwei Patienten wurden Rückfälle festgestellt, da noch nicht genügend Erfahrung auf diesem Gebiete gesammelt worden war. Mit Ausnahme eines Falles-Rückfall nach Operation eines Ellbogens- zeigten alle übrigen operierten Fälle eine merkliche Besserung der Gelenksamplitude.

20. Diese Untersuchungen scheinen aus, wertvolle Parameter geliefert zu haben, um zu bestimmen, wann eine POA voll ausgebildet ist und dazu dienen können, so dass die Operation mit einem Minimum an Risiko durchgeführt werden kann. Die Frage der Pathogenese der POA konnte bisher nur teilweise geklärt werden und weitere Untersuchungen sind notwendig, möglicherweise mit Hilfe von bio- und histochemischen Methoden.

Acknowledgements. The authors thank Dr. G. B. Ryan for his advice in the revision of the pathological study and Mrs. K. Sapounova, Mrs. A. De Almeida and Miss M. C. Clottu for technical help. They wish to thank Mr. A. Rondelli, Mr. A. Rychner and Mr. Ch. Ryser for drawing the tables and Dr. D. Grin for preparing the figures.

The manuscript was typed by Miss $M$. Fischer, to whom thanks are due.

\section{REFERENCES}

ALEX, R. (1959). Les para-ostéo-arthropathies neurogènes. A propos de I6 observations personnelles. Thesis, Lyon.

Armstrong-Ressy, C. T., Weiss, A. A. \& Ebel, A. (1959). Results of surgical treatment of extraosseous ossification in paraplegia. New York State F. Med., 59, 2548-2553.

BAud, C. A. \& LeE, H. S. (I969). Etude par diffraction des rayons X de l'incorporation in vivo du carbonate dans la substance minérale osseuse. C. R. Acad. Sc. Paris, D268, 2956-2957.

Bénassy, J. \& Combelles, Fr. (I97I). Ostéomes. Tentatives thérapeutiques. Ann. Méd. Phys, Paris, 14, 467-475.

Bénassy, J., Boissier, J. R., Patte, D. \& Diverres, J. Cl. (I960). Ostéomes des paraplégiques (Contribution à l'étude de l'ossification neurogène). Presse Médicale, 68, 8 I I$8 \mathrm{I} 4$.

Bénassy, J., Mazabraud, A. \& Diverres, J. (1963). L'ostéogénèse neurogène. Rev. Chir. Orthop. 49, 95-I I6.

BERNARD,Cl. (I859). Leçons sur les propriétés physiologiques et les altérations pathologiques des liquides de l'organisme. Vol. I. Douzième et treizième leçons, 266-294, Paris: J. B. Baillière.

BÉToUlik̀RES, A. (1962). Les ossifications para-articulaires neurogènes (O.P.N.). Presse Médicale, 70, I94-1 96.

BIDART, Y. \& MAURY, M. (1970). Les para-ostéo-arthropathies. Etat actuel du problème. Presse Médicale, 78, 2245-2248. 
Chantraine, A. (I97I). Clinical investigation of bone metabolism in spinal cord lesions. Int. F. Paraplegia, 8, 253-259.

Chantraine, A. (In press). Aspects cliniques et biologiques des para-ostéo-arthropathies. F. Rhumatol. et Méd. Phys.

CouvéE, L. M. J. (I97I). Heterotopic ossification and the surgical treatment of serious contractures. Int. F. Paraplegia, 9, 89-93.

DAmANSKi, M. (196I). Heterotopic ossification in paraplegia. A clinical study. $\mathcal{F}$. Bone $\mathfrak{f t}$. Surg. 43B, 286-299.

DÉJERINE \& CEILlIER, A. (I9I8). Para-ostéo-arthropathies des paraplégiques par lésion médullaire (Etude clinique et radiographique). Ann. Méd. 5, 497-535.

DÉJERINe, CEILlier, A. \& DÉJERINE, Yv. (I9I9). Para-ostéo-arthropathies des paraplégiques par lésion médullaire. Etude anatomique et histologique. Rev. Neurol. No. 5, 399-407.

FAUBEL, W. (I96I). Neurotrophische Gelenkveränderungen bei Querschnittsgelähmten. Verhandl. dtsch. Orthop. Ges. 49, 376-380.

FREEHAFER, A. A., YURICK, R. \& MAST, W. A. (1966). Para-articular ossification in spinal cord injury. Med. F. Serv., Canada, 22, 47I-477.

Furman, R., Nicholas, J. J. \& Jivoff, L. (I970). Elevation of the serum alkaline phosphatase coincident with ectopic-bone formation in paraplegic patients. F. Bone ft. Surg., 52A, II3I-II 37.

Galibert, P., Fossati, P., Lopez, C., Cecile, J. P., Bonte, G., Decoulx, P. \& Laine, E. (I96I). Etude angiographique de la circulation des membres inférieurs aux différents stades évolutifs d'une paraplégie. Neuro-Chir. 7, I8I-20I.

GRANT, R. T. (I929-I93I). Observations on direct communications between arteries and veins in the rabbit ear. Heart, 15, 28I-303.

Grogono, (I966). Discussion of the article 'Para-articular ossification in spinal cord injury'. Pp. 478. See ref. Freehafer et al.

Grueter, H. \& Busack, E. (I962). Beitrag zur Problematik von Amputationen bei Querschnittsgelähmten. Arch. Orthop. Unfall-Chir. 54, 295-300.

HARDY, A. G. \& Dickson, J. W. (I963). Pathological ossification in traumatic paraplegia. f. Bone ft. Surg. 45B, 76-87.

HossaCK, D. W. \& KING, A. (I967). Neurogenic heterotopic ossification. Med. F. Australia, I, 326-328.

Hutcheson, J., Klatte, E. C. \& Kremp, R. (I972). The angiographic appearance of myositis ossificans circumscripta. A case report. Radiology, 102, 57-58.

JEANNOPOULOS, C. L. \& LEVENTEN, E. O. (I96I). Unusual bilateral para-articular ossification of the elbows. F. Bone Ft. Surg. 43A, 876-880.

JowSEY, J. (1964). Variations in bone mineralisation with age and disease. In: Bone Biodynamics. Ed. H. M. Frost. Pp. 46I-479. Boston: Little Brown.

KäRCHER, K. H. (I972). Personal communication.

KIEF, W., KLEIN, B. \& MöLlER, E. (I972). Enzymbewegungen unter körperlicher Belastung bei trainierten und untrainierten Probanden. Med. Klin. 67, 195-199.

Klein, L., VAN DEN NoORT, S. \& DEJAK, J. J. (I966). Sequential studies of urinary hydroxyproline and serum alkaline phosphatase in acute paraplegia. Med. F. Serv., Canada, 22, 524-533.

Lejeune, E., Meunier, P., Ruitton, P. \& Orgiazzi, J. (I972). L'hydroxyprolinurie confrontée aux données histologiques osseuses quantitatives. Essai d'interprétation physiopathologique. Rev. Rhumat., 39, I07-II3.

Limbers, P. A. \& DonNAN, S. (I970). Widespread ectopic ossification following head injury. Med. F. Australia, 2, 540-54I.

Lopez, E., LeE, H. S. \& BAUD, C. A. (I970). Etude histophysique de l'os d'un Téléostéen, Anguilla anguilla L., au cours d'une hypercalcémie provoquée par la maturation expérimentale. C. R. Acad. Sc., Paris, D270, 201 5-20I7.

Mead, S., Cain, H. D., Kelly, R. E. \& Liebgold, H. (1963). Periarticular calcification in paraplegics: attempted treatment with disodium edetate. Int. F. Paraplegia, I, 62-68.

Michaelis, L. S. (I964). Orthopaedic surgery of the limbs in paraplegia, pp. 30-33. Berlin: Springer.

Miller, L. F. \& O’Neill, C. J. (I949). Myositis ossificans in paraplegics. F. Bone ft. Surg. 3IA, 283-294.

Muheim, G., Donath, A. \& Rossier, A. B. (in press). Serial scintigraphies in the course of ectopic-bone formation in paraplegic patients. Am. F. Roentgenol. (unpublished). 
Nechwatal, E. (I972). Die Vermeidung heterotoper Ossifikationen-ein zentrales Problem bei der Frühbehandlung von Querschnittgelähmten. Z. Orthop. II0, 590-596.

PosNer, A. S., EANES, E. D., HARPER, R. A. \& ZiPkIN, I. (I963). X-ray diffraction analysis of the effect of fluoride on human bone apatite. Arch. oral Biol. 8, 549-570.

RADT, P. (1970). Periarticular ectopic ossification in hemiplegics. Geriatrics, 25, I42-I 57.

Recordier, A. M., Mouren, P. \& Serratrice, G. (I96I). Les para-ostéo-arthropathies neurogènes. In: les ostéo-arthropathies nerveuses, pp. I I 7-I 27, Paris: Expansion Scientifique Française.

Rossier, A. B., Zender, R., Baquiche, M., Bahri, M. \& Courvoisier, B. (I972). Unpublished data.

ROUQUĖs, L., GEORGE \& HUARD (I954). Une pièce de para-ostéoarthropathie type DejerineCeillier. Rev. Neurol. 90, 233.

SHIFRIN, L. Z. (I970). Correlation of serum alkaline phosphatase with bone formation rates. Clin. Orthop. and Rel. Res. No. 70, 212-215.

Silver, J. R. (1969). Heterotopic ossification. A clinical study of its possible relationship to trauma. Int. F. Paraplegia, 7, 220-230.

Welch, K. M. A. \& GoldBerg, D. M. (I972). Serum creatine phosphokinase in motor neuron disease. Neurology, 22, 697-701.

ZENDER, R. (1972). Analyse de l'hydroxyproline urinaire. Méthode et valeurs fréquentes. Clin. Chim. Acta, 37, 263-269. 